\title{
Semantic Profiles of Five Russian Prefixes: po-, s-, za-, na-, pro-*
}

\author{
Laura A. Janda and Olga Lyashevskaya
}

\begin{abstract}
We test the hypothesis that Russian verbal prefixes express meaning even when they are used to create a "purely aspectual pair" (čistovidovaja para). This is contrary to traditional assumptions that prefixes in this function are semantically "empty." We analyze the semantic tags independently established in the Russian National Corpus (www.ruscorpora.ru) for 382 perfective partner verbs with five of the most common verbal prefixes in Russian: $p o-, s^{-}, z a-, n a-$, and pro-. Statistical tests show that the relationship between prefixes and semantic tags is significant and robust, and further identify which relationships constitute attractions, repulsions, and neutral relationships. It is possible to specify a unique meaning for each prefix in terms of the semantic tags it attracts or repulses. A detailed analysis of all the verbs in the study shows that the meanings of the prefixed perfective partners yield consistent patterns. Even verbs in repulsed semantic classes are consistent with these patterns. The meaning patterns of verbs with "purely aspectual" prefixes can be compared with the meanings of the prefixes as established on the basis of previous scholarship, which was primarily focused on the meanings of prefixes in their "non-empty" uses. This comparison shows that the verb meanings that appear with "purely perfectivizing" prefixes are the same as those found for "non-empty" uses of prefixes. We conclude that verbs select the prefix that is most compatible with their meanings when forming "purely aspectual" perfective partners, confirming our hypothesis.
\end{abstract}

\section{Introduction}

In terms of aspectual morphology, the Russian verbal lexicon is built from a set of simplex verbs, most of which are imperfective (like pisat' 'write'), to which prefixes and suffixes can be added. Prefixes usually perfectivize a verb and may or may not change the lexical meaning of the verb. For example, napisat' 'write' uses the prefix na- to perfectivize the verb without changing its meaning, whereas perepisat' 'rewrite' uses the prefix pere- to both perfectivize and alter the meaning of the

\footnotetext{
* This research was supported by the Norwegian Research Council and the University of Tromsø.
}

Journal of Slavic Linguistics 20(2): \#\#-\#\#, 2012. 
verb. The inventory of perfectivizing prefixes is discussed in 2.1. Three imperfectivizing suffixes (-aj, -vaj, and -ivaj) derive imperfective verbs from perfectives. The resulting verbs are usually referred to as "secondary imperfectives" and differ from their perfective correlates only in terms of aspect, as we see with perepisyvat' 'rewrite'. It is commonly assumed that aspectual pairs can be formed both by prefixation, when the prefix does not add new meaning, as in pisat' (imperfective) > napisat' (perfective) 'write', and by suffixation of prefixed perfectives, as in perepisat' (perfective) > perepisyvat' (imperfective) 'rewrite'. Schematically the two types of aspectual pairs can be represented thus:

$\begin{array}{llll} & \text { simplex } & \text { prefix+simplex } & \text { prefix+simplex+suffix } \\ \text { 'Write' } & \text { pisat' } & \begin{array}{l}\text { napisat' } \\ \text { perepisat' }\end{array} & \\ \text { 'rewrite' } & & \text { perepisyvat' } \\ & \text { imperfective } & \text { perfective } & \text { secondary imperfective }\end{array}$

This article focuses on the use of prefixes to form "purely aspectual" perfective partners to simplex imperfective verbs. Prefixes used for this purpose are claimed by many scholars to be devoid of meaning (beyond marking the verb as perfective) and thus semantically "empty" (Šaxmatov 1952, Avilova 1959 and 1976, Tixonov 1964 and 1998, Forsyth 1970, Vinogradov 1972, Švedova et al. 1980, Čertkova 1996, Zaliznjak and Šmelev 2000, Mironova 2004). The view that prefixes are "empty" when they serve the function of creating aspectual pairs rests upon a logical argument in which we assume that meanings are like mathematical values. Thus if " $\mathrm{m}$ " is the lexical meaning of a simplex verb " $\mathrm{s}$ ", we can assume that $\mathrm{m}=\mathrm{s}$ (for example, 'write' = pisat'). If we perfectivize " $\mathrm{s}$ " by adding a prefix " $\mathrm{p}$ ", the result, it is claimed, is a perfective verb that has the same lexical meaning as " $\mathrm{s}$ ", so $\mathrm{m}=\mathrm{p}+\mathrm{s}$ ("write' = napisat'). Since both " $\mathrm{s}$ " and " $\mathrm{p}+\mathrm{s}$ " equal " $\mathrm{m}$ ", the value of " $\mathrm{p}$ " by this logic is necessarily zero. In other words, the prefix has no meaning because the lexical meaning of the verb is not changed when it is added. All the prefix adds is the grammatical value "+ perfective", but that does not change the lexical meaning of the verb.

This is an elegant, attractive argument, but there are a number of phenomena it cannot explain. For example, why does Russian need more than one marker for "+ perfective"? Why do some verbs have 
more than one perfective partner verb, like gruzit' 'load', which has three: nagruzit', zagruzit', and pogruzit', all of which can be glossed as 'load'? Why is it the case that all of the prefixes that serve as "purely aspectual markers" can also form new lexical verbs in combination with other simplex verbs (cf. the meaning of "accumulation" in a verb like nagrešit' "commit many sins' vs. the "purely apsectual" use of nain napisat' 'write')? How do speakers of Russian know which prefix to use when a new verb is borrowed (as in zaasfal'tirovat' 'asphalt' and profil'trovat' 'filter')? These facts are better accounted for by an alternative model, according to which the prefixes do bear meaning even when they are used to create aspectual pairs (Vey 1952, van Schooneveld 1958, Isačenko 1960, Timberlake 2004: 410-11). Under this alternative model, it is hypothesized that the meanings of the prefixes overlap with the meanings of the simplex verbs. For example, one could say that the prefix $n a$ - is associated with accumulation on a surface, and pisat' 'write' is about accumulating symbols on a surface, motivating napisat' 'write'. Conceptual overlap works like camouflage, creating the illusion that the prefix is "empty" even though it is not.

These arguments against "empty" prefixes are not new, but they have not succeeded in reorienting the direction of scholarship in Slavic linguistics. Our goal is to provide both a new argument and a new methodology that takes this debate beyond the realm of a polemical essay by looking at a statistical analysis of the relationships between prefixes that are used to form aspectual pairs and semantic classes. This study is part of a series of studies that give evidence in support of the overlap model.

The semantic profiling method described in this article is part of a suite of related methodologies for probing the statistical behavior of linguistic units, including also constructional profiling (Janda and Solovyev 2009, Sokolova, Janda, and Lyashevskaya forthcoming), grammatical profiling (Janda and Lyashevskaya 2011a), and radial category profiling (Nesset, Janda, and Endresen 2011, Endresen et al. submitted). These methodologies are inspired by behavioral profiling, which investigates the distribution of a variety of features (morphological, semantic, syntactic, lexical, etc.) in connection with linguistic units, particularly as developed by Divjak and Gries (Divjak and Gries 2006, Gries and Divjak 2009).

It is important to differentiate between verbs in which the prefixes are claimed to be "empty" and those where the prefixes are "non- 
empty." Scholars in both formalist and functionalist traditions have proposed that distinctions be made among Russian perfective verbs. Svenonius and Ramchand (Ramchand 2004, Svenonius 2004a, 2004b, and 2008) identify three groups of perfectives: those with "purely perfectivizing" prefixes (such as napisat' "write'), which they set aside and do not analyze further; those with "lexical" prefixes, which have directional or idiosyncratic meanings (such as perepisat' 'rewrite'), and those with "super-lexical" prefixes, which have predictable, quantizing meanings (such as popisat' 'write for a while', počixat' 'sneeze for a while'). Svenonius and Ramchand point out that whereas "lexical" prefixes introduce additional predicational structure, add arguments, and are low in the tree (VP-internal), "super-lexical" prefixes do not introduce additional predicational structure, do not add arguments, and are high in the tree (VP-external). In a largely parallel classification, ${ }^{1}$ Janda (2007) suggests the term "Natural Perfectives" for verbs formed with "purely perfectivizing" prefixes, "Specialized Perfectives" for verbs formed with "lexical" prefixes, and "Complex Act Perfectives" for verbs formed with "super-lexical" prefixes. Janda additionally identifies "Single Act Perfectives" with a semelfactive meaning (such as čixnut' 'sneeze once') and shows that the types of perfectives have distinct tendencies in terms of their semantics and derivational behavior. Whereas Specialized Perfectives nearly always form secondary imperfectives, this type of derivation is resisted to various degrees by the other types of perfectives. Natural Perfectives and Specialized Perfectives usually refer to actions that have a natural culmination (the completion of a document for napisat' 'write' or a revision for perepisat' 'rewrite'); by contrast, Complex Act Perfectives and Single Act Perfectives usually refer to actions that lack a sense of completability (popisat' 'write for a while' is about writing without an inherent telos, and the lack of a culmination is inherent in sneezing as we see in počixat' 'sneeze for a while' and čixnut' 'sneeze once'). Natural Perfectives tend to behave like a closed-class category, with a limited type frequency (under 2,000 verbs; see below) and relatively high token frequency (the average median frequency of a Natural Perfective in the

\footnotetext{
${ }^{1}$ There are some minor differences in the two classifications, but they do not impact the argument in this article and are therefore not discussed. Janda's (2007) classification has been extended in subsequent work (Makarova and Janda 2009), but this also goes beyond the scope of the present article.
} 
Russian National Corpus is 107), whereas other perfectives are an open class with unlimited type frequency (permitting occasionalisms) and relatively low token frequency (average median token frequency 9.7; cf. Kuznetsova 2010). Admittedly there is no perfect dividing line between Natural Perfectives and other perfectives. However, there are very strong tendencies in this system, and the case of most verbs is clear despite the existence of some controversial examples.

In this article we adopt Janda's (2007) terminology. Thus, the aspectual partner verbs formed by "purely perfectivizing" prefixes are henceforth referred to as "Natural Perfectives." We state our hypothesis as (1):

(1) Hypothesis: The selection of prefixes for Natural Perfectives conforms to semantic preferences.

This hypothesis will be tested using a statistical study of the semantics of Natural Perfectives formed via prefixation. In order to test the hypothesis, we need first to clearly define the set of Natural Perfectives and find a means for objectively assessing semantic preferences. These two challenges have been overcome by means of electronic resources that provide a comprehensive list of relevant verbs and semantic tags for those verbs, respectively. Those resources are described below.

Whereas a distinction between Natural Perfectives and all other prefixed perfectives is well motivated regardless of what tradition one adheres to, there is a challenge in finding a method that will yield an uncontroversial list of all and only the Natural Perfectives in Russian. Our approach was to compare all perfectives listed in authoritative sources and further subject this list to review by native speakers in order to get as exhaustive a list of Natural Perfectives as possible by starting from objective third-party sources. The CLEAR (Cognitive Linguistics: Empirical Approaches to Russian) group at the University of Tromsø has prepared an inventory of Russian Natural Perfectives available over the internet at http://emptyprefixes.uit.no. This inventory, called the Exploring Emptiness database, provides information on all 1,981 Natural Perfectives formed via prefixation, including all such perfectives listed in two dictionaries plus a list, and vetted by a panel 
of native speakers. ${ }^{2}$ This study uses the Exploring Emptiness database as the point of departure and the full range of relevant Natural Perfectives represented there.

The semantic value of words is a complex issue, particularly in an empirical study which should ideally use objective measures. The builders of the Russian National Corpus (www.ruscorpora.ru; henceforth "RNC") have developed a system of semantic tags that is adapted from the work of the "Leksikograf" group (http://lexicograf.ru/main.html; cf. also Padučeva 2004, Kustova et al. 2005 and 2009), and more generally inspired by the work of the Moscow Semantic School (cf. Apresjan 2005). ${ }^{3}$ The RNC semantic tags thus represent the collective experience of outstanding linguists who have pursued the semantic description of Russian. A crucial issue for our study is the fact that the semantic tags have been developed and assigned independently, thus achieving a level of objectivity we could not provide if we were to devise and tag relevant verbs ourselves. At the present time many words in the RNC have not yet received a semantic tag, and it is unlikely that semantic tagging will ever be extended to the entire lexicon. The full list of Natural Perfectives in the Exploring Emptiness database was compared with the inventory of verbs found in the RNC. On the basis of this comparison we found that $92 \%$ of the Natural Perfectives attested in the RNC have been assigned a semantic tag, ${ }^{4}$ and our semantic investigation is based upon these tags. Given the fact that this study uses the RNC tags in order to classify verbs according to semantics, we can modify the hypothesis to read as in (1a):

(1) a. Hypothesis: The selection of prefixes for Natural Perfectives conforms to preferences for semantic tags.

The set of preferences for semantic tags that can be found for a verb with a given prefix is referred to as the "semantic profile" of the

\footnotetext{
2 The sources are: Evgen'eva 1999, Ožegov and Švedova 2001, and Cubberly 1982. The panel of native speakers are: Julia Kuznetsova, Olga Lyashevskaya, Anastasia Makarova, and Svetlana Sokolova.

${ }^{3}$ Details on what kinds of issues were faced and how problems were solved in developing the semantic tags are found in Kustova et al. 2009.

${ }^{4}$ We would like to thank Galina Kustova for her efforts to maximize the tagging of verbs in the RNC.
} 
prefix. As we show below, each prefix has a unique semantic profile, attracting and repulsing various semantic tags each in its own way.

We discuss the semantic profiling method in Section 2, detailing how we selected the prefixes, semantic tags, and verbs that are included in this study. Section 3 presents a statistical analysis demonstrating that the prefixes $p o^{-}, s^{-}, z a^{-}, n a^{-}$, pro- have distinct semantic profiles and identifying which specific tags each prefix attracts and repulses. Section 4 delves deeper, analyzing each group of verbs associated with a specific prefix and tag. Here we show that the meanings of the Natural Perfectives for a given prefix correspond to the meanings of the same prefix as established on the basis of other types of perfectives. We also find that the meanings of the residue of verbs in repulsed semantic classes are consistent with the meanings of both the prefix and the verbs in the corresponding attracted classes. Conclusions are offered in Section 5.

\section{Data and Methodology}

Any quantitative study entails making decisions about what kind of data to include so that the sample is representative, free of errors or factors that might obscure the phenomenon of study, and suitable for statistical analysis. Our study aims to test the hypothesis that the prefixes in Natural Perfectives are not distributed randomly, but show preferences for semantic classes. We test this hypothesis on the basis of a dataset that is necessarily limited by the constraints of a statistical model. However, limiting the data in this way does not detract from the validity of this study as a test of the hypothesis. Furthermore, the data that have been set aside, for reasons outlined below, can and have been addressed in other ways (see especially Endresen et al. submitted, Janda and Lyashevkaya 2011b, and Sokolova, Janda, and Lyashevskaya in press). The following subsections detail how we selected the set of prefixes and semantic classes for this study and the measures we took to eliminate extraneous factors from the dataset.

Additionally we need to observe the assumptions and limitations of the statistical model that we use to test the significance of the outcome. Any statistical model makes some absolute requirements on the structure of the data, and they must be observed because any violation will invalidate the use of the model. In other words, the findings would be falsified and it would be fraudulent to report such findings if 
the assumptions and limitations are not taken into account. Our model of choice, the chi-square test, assumes that all observations are independent and cannot tolerate any expected value of less than five. The assumption of independence means that it is important to avoid overlapping data, so no one verb can be represented more than once in the dataset. Due to the independence assumption we need to control for situations in which verbs are associated with multiple prefixes or multiple semantic classes. The limitation on expected values means that we face paucity of data problems with a matrix that represents all prefixes and all semantic classes. With sixteen rows for prefixes (see 2.1) and twenty-seven columns for semantic classes (see 2.2), such a matrix would have 432 cells. Since there are only 1,981 prefixed Natural Perfectives in Russian (as identified in the Exploring Emptiness database), there are simply not enough Natural Perfectives in Russian to populate this matrix to a level that would give more than five observations for every cell. The uneven distribution of the data and the fact that some data must be eliminated in order to adhere to the independence assumption further compound this problem, so it is necessary to limit this study to the prefixes and semantic classes that are associated with the largest numbers of verbs.

\subsection{Which Prefixes and Why}

As the title states, this study is limited to five prefixes: $p o^{-}, s^{-}, z a-, n a-$, and pro-. This subsection details the rationale behind choosing those prefixes and further measures that were taken to prepare the data sample related to selection of prefixes.

Due to issues of allomorphy there is some room for controversy concerning the number of prefixes that form Natural Perfectives in Russian. We take as our starting point Krongauz's (1998) list of nineteen prefixes, which we can reduce to sixteen by collapsing $\mathrm{O}^{-}, \mathrm{ob}-$, and $o b o-$, on the one hand, and $v z-$ and voz- on the other. ${ }^{5}$ The distribution

\footnotetext{
${ }^{5}$ Many major Russian grammars and scholarly works treat $o$-/ob-/obo- as a single prefix, including Zaliznjak and Šmelev 1997: 73; Zaliznjak and Šmelev 2000: 83; Wade 1992: 277; Timberlake 2004: 404; Townsend 1975: 127; Grammatika russkogo jazyka 1952, 1: 589-92; Isačenko 1960: 148; Barykina, Dobrovol'skaja, and Merzon 1979; Hougaard 1973; and Roberts 1981. Alexeeva 1978, Andrews 1984, and Krongauz 1998: 131-48 present the opposing view that there are two distinct prefixes: $o$ - and $o b(o)$-. Baydimirova (2010) conducted a comprehensive review of both Natural and Special-
} 
of these sixteen prefixes across all Natural Perfectives found in the Exploring Emptiness database is represented in Figure 1.

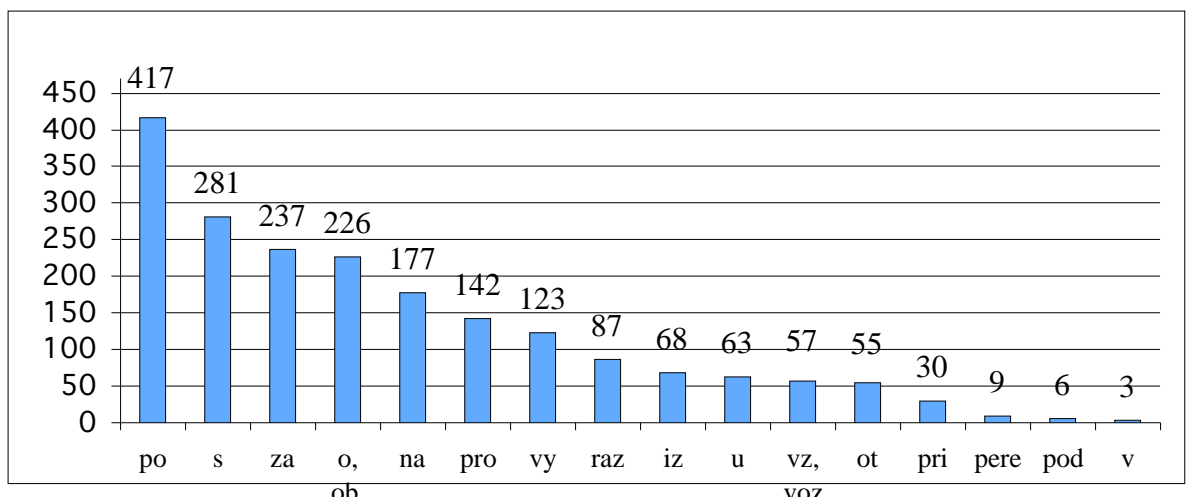

Figure 1. Distribution of aspectual prefixes across Natural Perfectives

Figure 1 makes it easy to identify the prefixes that form the largest numbers of Natural Perfectives. The question is where to draw the line in this distribution, which prefixes from the left to include, and which from the right to exclude. We took a variety of facts into consideration in making our decision. There is a break in the distribution between the "large" prefixes, with over one hundred Natural Perfectives (po-, s, za-, o-/ob-/obo-, na-, pro-, and $v y-)$, and the "small" prefixes, with fewer Natural Perfectives (raz-, iz-, u-, vz-/voz-, ot-, pri-, pere-, pod-, and v-). This is a good place to start, but this breaking point presents two problems. On the one hand, this division separates $v y$ - and $i z$-into two different groups, which is imprudent given the fact that these two prefixes have co-evolved in a special relationship that would be obscured by setting them apart from each other (cf. the detailed analysis in Nesset, Janda, and Endresen 2011). Including both $v y$ - and $i z$ - would run us afoul of the assumption of independence of observations, since

ized perfectives prefixed in $0-/ o b-/ o b o-$, complemented by a psycholinguistic experiment using nonce words. Her results show that all three variants cover all available submeanings, thus supporting the majority view that they are variants rather than distinct prefixes.

In considering $v z$ - and voz- to be a single prefix, we follow Townsend (1975: 123). By contrast, Isačenko (1960: 149), Švedova et al. (1980: 357-58), and Vinogradova (1984: 24-26) list vz- and voz- as two prefixes that differ in register. Endresen and Sokolova (2011) revisited this problem and concluded that despite minor differences, the two variants overlap in all their meanings. 
these two prefixes are not independent of each other, and $i z$ - has sparse data. So there are good reasons to remove $v y$ - and $i z$-from this study. On the other hand, we have the situation of $0-/ o b-/ o b o-$, which presents a unique array of relationships involving phonology, morphology, and semantics. It would be difficult, or maybe even impossible to include $o$-/ob-/obo- in this dataset without violating the independence assumption of our statistical model and thus invalidating the entire study. Given these problems, the best solution is to take the largest prefixes, excluding $o-/ o b-/ o b o-$ and stopping before $v y$-. This gives us five prefixes: $p o^{-}, s^{-}, z a-, n a-$, and pro-.

Fortunately, restricting the scope to five prefixes does not compromise the present study or the overall goal of demonstrating that the prefixes that form Natural Perfectives are not semantically "empty." The remaining five prefixes are all very frequent, and are associated with over $63 \%$ of all prefixed Natural Perfectives in Russian, so we retain the bulk of the data. Furthermore, two other studies address in detail the meanings that are present in the other eleven prefixes: Baydimirova 2010 presents corpus and experimental data for $o-/ o b$ lobo-, and Endresen et al. submitted examines the ten smallest prefixes (ranging from $v y$ - to $v$-). Both of these studies establish the meanings of prefixes based on their "non-empty" uses (in Specialized Perfectives and Complex Act Perfectives) and show that these meanings overlap with the meanings of the base verbs that form Natural Perfectives with the same prefix. The radial category profiling methodology used in Baydimirova 2010 and Endresen et al. submitted could in principle be extended to all the prefixes, but in the case of the larger prefixes would involve labor-intensive attention to many thousands of verbs. The meanings of the larger prefixes, particularly po- (which is becoming a "default" perfectivizer in Russian; cf. Dickey 2006 and 2007), are also more semantically diffuse and more challenging for a radial category profiling analysis. For these reasons, the semantic profiling methodology is more appropriate for the larger prefixes. Note, however, that some studies have explored radial categories also for the larger prefixes (LeBlanc 2010 on po-; Janda 1986, Shull 2003, Zaliznjak 2006, and Braginsky 2008 on $z a-$ ).

To summarize, it makes sense to divide the prefixes into a "large" and a "small" group according to the number of Natural Perfectives they are associated with. The large prefixes are both quantitatively and qualitatively different from the small prefixes, motivating different 
approaches for the two groups. The small prefixes can be analyzed in the exhaustive detail required by radial category profiling, but present too few data for semantic profiling. The large prefixes present overwhelming and diffuse data that are hard to handle for radial category profiling but potentially sufficient for semantic profiling. If we take the five "largest" prefixes, excluding $o-/ o b-/ o b o-d u e$ to confounding factors, we have $p 0^{-}, s^{-}, z a-, n a-$, and pro-. The next challenge is to make sure that all the observations of the large prefixes are independent, which brings us to the issue of prefix variation.

Prefix variation is present when an imperfective base verb forms two or more Natural Perfectives with the same lexical meaning. For example, if we look up pisat' 'write' in Ožegov and Švedova 2001, we find that it has one aspectual partner verb, napisat'. But if we look up gruzit' 'load' in the same dictionary, we find that it has not one, but three aspectual partner verbs: pogruzit', nagruzit', and zagruzit'. Though prefix variation is well attested in dictionaries, this phenomenon has been largely overlooked, perhaps because it is at odds with the traditional description of aspect as involving "pairs" of verbs. However prefix variation is not as marginal as one might suspect: $27 \%$ of imperfective verbs that form Natural Perfectives via prefixation form two, three, four, five, or even six prefixed aspectual partner verbs (for a detailed analysis of prefix variation, see Janda and Lyashevskaya 2011b).

Prefix variation is a problematic factor for a chi-square analysis because it violates the assumption of independence of observations. We can think of verbs as "voters" and prefixes as "candidates", where a statistical model is applied to test voting trends. From this perspective, pisat' 'write' casts only one vote, namely for the prefix na-, while gruzit' 'load' casts three votes, for po-, na-, and $z a-$. Thus gruzit' 'load' is illegally stuffing the ballot box and invalidating the statistical model. The solution we apply is to eliminate all verbs that show prefix variation from the study. The total number of verbs prefixed in $p 0^{-}, s^{-}, z a^{-}, n a^{-}$, and pro- that are associated with the semantic classes included in the study (see 2.2) is 719. Elimination of prefix variation reduces this number to 395 verbs. The next step is to describe how the largest semantic 
classes relevant for our prefixes were selected and apply a similar measure to avoid verbs that belong to more than one semantic class. ${ }^{6}$

\subsection{Which Semantic Tags and Why}

This subsection describes the semantic tags for verbs found in the RNC; why we select the following tags for inclusion in our study: IMPACT, CHANGEST, BEHAV, and a combined class of SOUND and SPEECH; and how verbs with multiple semantic tags were eliminated from the study.

The RNC applies twenty-seven thematic lexico-semantic tags to verbs. The descriptions and examples listed in this subsection are quoted from the RNC website, and thus apply to verbs in general, not specifically to prefixed Natural Perfectives. About half of the tags (fourteen of them) are connected to larger groups. For example, there are three tags labeled IMPACT: a generalized group labeled merely IMPACT (characterized as fizičeskoe vozdejstvie 'physical impact' with examples bit' 'hit', kolot' 'stab', and vytirat' 'wipe, rub'), plus two more specialized sub-groups: IMPACT:CREAT (sozdanie fizičeskogo ob"ekta 'creation of a physical object', such as vykovat' 'forge', smasterit' 'craft, build', sšit' 'sew') and IMPACT:DESTR (uničtoženie 'destruction', as in vzorvat' 'explode', sžeč' 'burn', zarezat' 'slaughter'). Other grouped tags are MOVE (subgroups: MOVE, MOVE:BODY), BE (subgroups: BE, BE:EXIST, BE:APPEAR, BE:DISAPP), LOC (subgroups: LOC, LOC:BODY), and PSYCH (subgroups: PSYCH, PSYCH:EMOT, PSYCH:VOLIT).

\footnotetext{
${ }^{6}$ There are other ways to approach the meanings of prefixes in the context of prefix variation. For example, it is possible to explore the semantics of simplex verbs that engage in prefix variation and analyze to what extent the meanings of the prefixes create verbs that are interchangeable or contrastive in various environments, as in Janda and Lyashevskaya 2011b. Another alternative is to explore differences in the grammatical constructions associated with competing Natural Perfectives. For example, Sokolova, Janda, and Lyashevskaya (forthcoming) show on the basis of a logistic regression model that whereas the three Natural Perfectives of gruzit' 'load' can all be used with both the theme-object construction (gruzit' seno na telegu 'load hay onto the cart') and the goal-object construction (gruzit' telegu senom 'load the cart with hay'), they show distinctly different preferences: pogruzit' has a very strong preference for the theme-object construction, nagruzit' has a preference for the goal-object construction, and zagruzit' has a more balanced distribution between the two constructions (strong affected by metaphorical uses). These findings, however, go beyond the scope of the present study.
} 
The remaining thirteen tags are ungrouped categories, and four of them are pertinent to our study. CHANGEST is characterized as izmenenie sostojanija ili priznaka 'change of state or feature' (examples: vzroslet' 'mature', bogatet' 'get rich', rasširit' 'spread', ispačkat' 'soil'). BEHAV is characterized as povedenie čeloveka 'human behavior' (examples: kurolesit' 'play pranks', priveredničat' 'act fussy'). SOUND is characterized as zvuk 'sound' (examples: gudet' 'buzz', šelestet' 'rustle'). SPEECH is characterized as reč' 'speech' (examples: govorit' 'talk', sovetovat' 'advise', sporit' 'argue', kalamburit' 'make puns').

Semantic classes were selected according to the number of Natural Perfectives prefixed in $\mathrm{po}^{-}, \mathrm{s}^{-}, \mathrm{za-}, \mathrm{na-}$, and pro- they are associated with. As with the selection of prefixes, the goal was to select the semantic classes that yielded the largest numbers of verbs. We needed to ensure that no cell in our matrix would have fewer than five expected observations (prefixed verbs), even with large fluctuations in distribution and after elimination of multiply tagged verbs. Therefore we set a threshold of fifty for the number of verbs in each class. In other words, we only included semantic classes with fifty or more prefixed Natural Perfectives in order to make sure that we would have enough data for our analysis. The IMPACT class (including both IMPACT:CREAT and IMPACT:DESTR) is the biggest class for our prefixes, with a total of 127 verbs. The next largest class is CHANGEST, which is tagged on 103 Natural Perfectives with the relevant prefixes. We merge the SOUND and SPEECH classes (henceforth SOUNDANDSPEECH) on the grounds that they are all verbs denoting the making of sounds, with the latter being more specific to human beings. Together this combined class has 111 Natural Perfectives with our five prefixes. The next largest class is BEHAV, with fifty-four Natural Perfectives. No other semantic class crosses our threshold of fifty.

As with prefixes, we need to avoid collecting multiple observations of semantic classes from any one verb. We thus eliminated from the study any verb that is tagged with more than one of the semantic classes we retained. Fortunately there were not many verbs that needed to be eliminated in this round, only five in the IMPACT class, one in the CHANGEST class, two in the BEHAV class, and five in the combined SOUNDANDSPEECH class. This leaves 382 Natural Perfectives prefixed in $p 0^{-}, s^{-}, z a-, n a-$, and pro- for the analysis in Section 3. 


\section{Statistical Analysis}

Our aim is to test the hypothesis that the choice of the prefix is related to the meaning of the verb as reflected by its semantic tag. The chisquare test can tell us the probability that the distribution we observe is merely a random event with no significance. A low probability will thus support our hypothesis.

Table 1 presents the distribution of our five prefixes vs. the four semantic classes. The top portion of the table gives the raw scores, which are the numbers of verbs with the given prefixes and the given semantic classes. In other words, if we look at the top row of figures in Table 1, it tells us that of the verbs prefixed in po-, 11 have the IMPACT tag, 62 have the CHANGEST tag, 11 have the BEHAV tag, and 37 have the SOUND and SPEECH tags. This top portion of Table 1 is visualized in Figure 2, which gives us a first glance of the semantic profiles of the five prefixes.

Table 1. Distribution of Prefixes vs. Semantic Classes

\begin{tabular}{|c|c|c|c|c|}
\hline & IMPACT & CHANGEST & BEHAV & SOUNDANDSPEECH \\
\hline & \multicolumn{4}{|c|}{ Raw Values } \\
\hline po- & 11 & 62 & 11 & 37 \\
\hline$s-$ & 23 & 11 & 23 & 9 \\
\hline$n a-$ & 31 & 3 & 17 & 8 \\
\hline$z a-$ & 47 & 22 & 1 & 1 \\
\hline pro- & 10 & 4 & 0 & 51 \\
\hline \multicolumn{5}{|c|}{ Expected Values (rounded to the nearest integer) } \\
\hline po- & 39 & 32 & 16 & 34 \\
\hline$s^{-}$ & 21 & 18 & 9 & 18 \\
\hline$n a-$ & 19 & 16 & 8 & 16 \\
\hline$z a-$ & 22 & 19 & 10 & 20 \\
\hline pro- & 21 & 17 & 9 & 18 \\
\hline \multicolumn{5}{|c|}{ Observed-Expected Values } \\
\hline po- & -28 & 30 & -5 & 3 \\
\hline$s^{-}$ & 2 & -7 & 14 & -9 \\
\hline$n a-$ & 12 & -13 & 9 & -8 \\
\hline$z a-$ & 24 & 3 & -9 & -19 \\
\hline pro- & -11 & -13 & -9 & 33 \\
\hline
\end{tabular}


Fisher Test p-value (probability that Observed-Expected could be greater)

\begin{tabular}{lllll} 
po- & 0.0002 & $1.3^{\mathrm{e}-18}$ & 0.05 & 0.0008 \\
$s^{-}$ & 0.015 & 0.3 & $2.1^{\mathrm{e}-8}$ & 0.1 \\
$n a-$ & $5.3^{\mathrm{e}-7}$ & 0.001 & $5.5^{\mathrm{e}-5}$ & 0.1 \\
$z a-$ & $1.5^{\mathrm{e}-15}$ & 0.01 & 0.002 & $2.0^{\mathrm{e}-6}$ \\
pro- & 0.1 & 0.002 & 0.0005 & $5.7^{\mathrm{e}-25}$ \\
\hline
\end{tabular}

IMPACT $\square$ CHANGEST $\mathrm{B} B E H A V$ 图S\&S

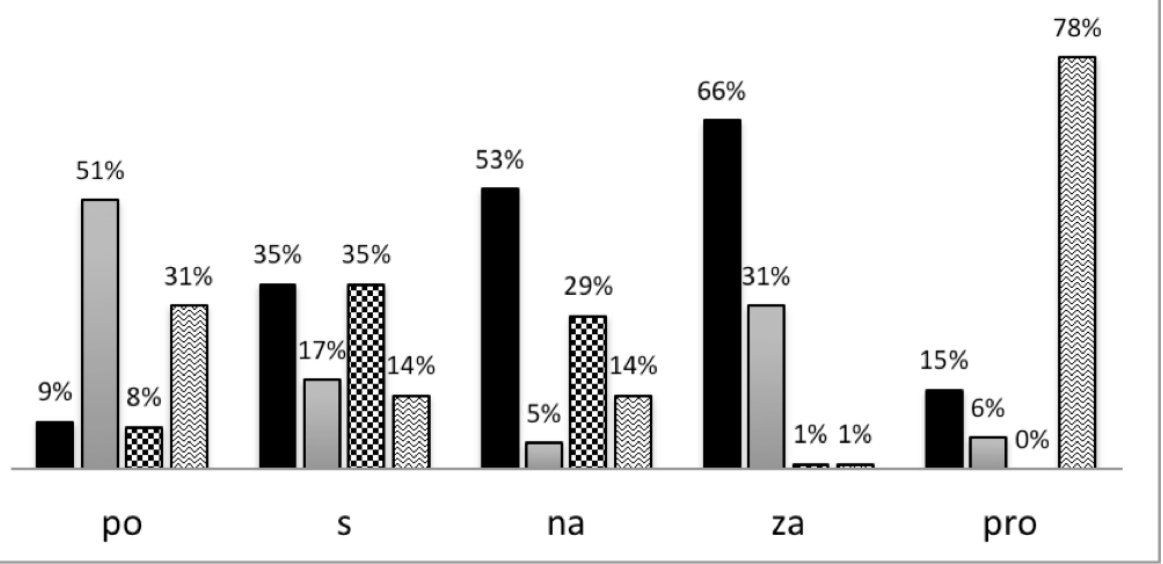

Figure 2. Semantic profiles of $p o_{-}^{-,} s_{-}^{-,} n a_{-}^{-}, z a_{-}^{-}$, and pro-

Figure 2 presents the semantic profile of each prefix, with the values given as percentages so that they are on the same scale, and the sum of all bars in each cluster at $100 \%$ ( $\pm 1 \%$ due to rounding). We see that each prefix behaves differently: po- favors CHANGEST, while prois nearly entirely dominated by SOUNDANDSPEECH. IMPACT makes a strong showing in $s^{-}, n a^{-}$, and $z a-$, but the balance of other semantic classes is different for each one. While Figure 2 gives us some insights, the data do not fully reflect all the relevant relationships and are not yet balanced according to the different overall totals for the prefixes and semantic classes. This is achieved in the remaining three portions of Table 1.

While we can see differences among the prefixes in Figure 2, we need to conduct statistical tests in order to find out whether these dif- 
ferences are significant and robust. For this purpose we apply the chisquare test for significance and a test of effect size to measure robustness. The chi-squared value for the matrix in the top portion of Table 1 is 248 (with $\mathrm{df}=12$ ), and the probability that this distribution is a random event is $2.2^{\mathrm{e}-16}$ (or 0.00000000000000022 ), which is the lowest number computed by the " $\mathrm{R}$ " statistical software package. In other words, the result is statistically very significant. Additionally, the effect size computed for this result is 0.81 . Effect sizes range from 0 to 1 and an effect size of 0.1 is considered "small," 0.3 is considered "moderate", and 0.5 is considered "large" (Cohen 1988: 215-71; Cohen et al. 2003: 182; King and Minium 2008: 327-30). Thus the effect size far exceeds the standard measure for a large effect.

The second portion of Table 1, labeled "Expected Values," shows the expected value for each cell. The expected value in any cell can be calculated according to this formula: expected value $=$ (row sum $x$ column sum) / total sum. So, for example, look at the upper right-hand cell of Table 1, where we have 11 po-prefixed verbs with the IMPACT tag. The total number of observations in this row is $11+62+11+37=$ 121. The total number of observations in this column is $11+23+31+$ $47+10=122$. The total number of observations in the table is 382 . So the expected value for this cell (the value we would get if the data were distributed evenly) is $(121 \times 122) / 382=38.64398$, which we can round to 39 , and that is the number we find in the corresponding cell of the second portion of Table 1. Crucially we see that the lowest expected value is 8 (for the prefix $n a$ - and the semantic class BEHAV), so all expected values exceed 5. This means that the distribution of data is indeed appropriate for use of the chi-square test described above.

The third portion of Table 1, labeled "Observed-Expected," lists the difference between the number of verbs found with the given combination of prefix and semantic class, minus the expected value for the same cell in the matrix. If we look again at the cell representing poprefixed IMPACT verbs, we see that the observed number is 11, and the expected value is 39 , so the difference is $11-39=-28$, which is also the lowest number in this portion of the table. Positive values here indicate attraction, whereas negative values indicate repulsion. For example, the largest positive value is found for verbs with the pro- prefix and the SOUNDANDSPEECH semantic tag, since the observed value (51) is 33 more than what would be expected (18). The least deviation from overall frequency-based expectations is for verbs prefixed in $s$ - 
with the IMPACT class, since the actual number of 23 is very close to the expected number of 21.

While the raw scores give some indication of attractions and repulsions, they need to be calibrated to the same scale and tested for statistical significance so that they can be meaningfully compared. This is achieved by using the Fisher Test, which calculates for every cell the probability that the observed value could deviate more from the expected value, given the overall distribution of values. The bottom portion of Table 1 reports the Fisher Test p-values for all cells. ${ }^{7}$ For example, in the upper left cell we see the value 0.0002 for po- and IMPACT. We know that po- is repulsed from IMPACT because the expected value is 39 , but the actual value is only 11 . The Fisher Test p-value reports the chance that we would find a value lower than 11 in this cell. Since the Fisher Test $p$-value is 0.0002 , this means that the chance of finding fewer than 11 po-prefixed verbs with the IMPACT semantic tag is 1 in 20,000 . In other words, we observe a strong repulsion. If we look at the opposite corner of the table, in the bottom right, we find the Fisher Test $\mathrm{p}$-value for the cell representing pro-prefixed verbs tagged for SOUNDANDSPEECH, which is $5.7^{\mathrm{e}-25}$. Since the observed value exceeds the expected value in this cell, the Fisher Test p-value we report is for the chance that we would find more than 51 pro-prefixed verbs tagged for SOUNDANDSPEECH. The chance this could happen is extremely low, namely 5.7 with the decimal moved 25 places to the left. Again, we are dealing with a very significant relationship, this time an attraction.

For the purposes of this article, we will report as attractions and repulsions only those combinations for which the Fisher Test $p$-value is equal to or lower than 0.01 (a 1/100 chance); higher values will be

\footnotetext{
${ }^{7}$ The Fisher Test p-value is computed the same way for each cell, so one example here suffices. If we look at po- and IMPACT in the top portion of Table 1, we find 11 verbs in that cell. To compute the Fisher Test p-value we also use three other values that reflect the relationship of this number to the overall numbers: the number of verbs that have the IMPACT tag but a prefix other than po- $(23+31+47+10=110)$, the number of verbs prefixed in po- that do not have the IMPACT tag $(62+11+37=111)$, and the number of verbs that do not have the po- prefix with the IMPACT tag (total 382-11=371). Together, these four numbers are input to the Fisher Test, which tells us the likelihood that we could have a deviation even greater from the expected value given the overall values. Fisher test $p$-values were computed using the following online calculator: http://research.microsoft.com/en-us/um/redmond/projects/mscompbio/FisherExactTest/.
} 
rated as neutral relationships since 0.01 is a standard threshold for recognizing statistical significance. Some of the relationships are not significant (and thus neutral) according to this measure. For example, the Fisher Test $\mathrm{p}$-value of 0.3 for $s$-prefixed verbs tagged for CHANGEST tells us there is a $30 \%$ chance of finding fewer than 11 such verbs. Three other repulsions have Fisher Test p-values of 0.1 (pro-/IMPACT, $s$-/SOUNDANDSPEECH, na-/SOUNDANDSPEECH), meaning there is a $10 \%$ chance there could have been smaller observed values.

The array of Fisher Test p-values can be rearranged to show which combinations are most strongly attracted, which are neutral, and which are most strongly repulsed, as in Table 2.

Table 2. Attractions, Neutral Relationships, and Repulsions between Prefixes and Semantic Classes ${ }^{8}$

\begin{tabular}{|c|c|c|c|c|c|}
\hline \multicolumn{2}{|c|}{ Attractions } & \multicolumn{2}{|c|}{ Neutral } & \multicolumn{2}{|c|}{ Repulsions } \\
\hline Combination & $\begin{array}{l}\text { Fisher } \\
\text { Test } \\
\text { p-value }\end{array}$ & Combination & $\begin{array}{l}\text { Fisher } \\
\text { Test } \\
\text { p-value }\end{array}$ & Combination & $\begin{array}{l}\text { Fisher } \\
\text { Test } \\
\text { p-value }\end{array}$ \\
\hline pro-/SANDS & {$[+] 5.7^{\mathrm{e}-25}$} & $s$-/CHANGEST & {$[-] 0.3$} & $z a-/$ SANDS & {$[-] 2.0^{\mathrm{e}-6}$} \\
\hline po-/CHANGEST & {$[+] 1.3^{\mathrm{e}-18}$} & pro-/IMPACT & {$[-] 0.1$} & po-/IMPACT & {$[-] 0.0002$} \\
\hline$z a$-/IMPACT & {$[+] 1.5^{\mathrm{e}-15}$} & $s$-/SANDS & {$[-] 0.1$} & pro-/BEHAV & {$[-] 0.0004$} \\
\hline$s$-/BEHAV & {$[+] 2.1^{\mathrm{e}-8}$} & $n a-/ S A N D S$ & {$[-] 0.1$} & $n a-/ C H A N G E S T$ & {$[-] 0.001$} \\
\hline na-/IMPACT & {$[+] 5.3^{\mathrm{e}-7}$} & po-/BEHAV & {$[-] 0.05$} & $z a-/ \mathrm{BEHAV}$ & {$[-] 0.002$} \\
\hline na-/BEHAV & {$[+] 5.5^{\mathrm{e}-5}$} & $s$-/IMPACT & {$[+] 0.015$} & pro-/CHANGEST & {$[-] 0.002$} \\
\hline po-/SANDS & {$[+] 0.0008$} & & & & \\
\hline$z a-/ C H A N G E S T$ & {$[+] 0.01$} & & & & \\
\hline
\end{tabular}

Table 2 is arranged according to the strength of the given relationship. Thus the most attracted, most repulsed, and most neutral relationships are at the top of each column, and the remaining scores are given in descending order. The most neutral relationships are those where the actual numbers of verbs are closest to the expected values. Table 2 uses the notation $[+]$ and $[-]$ to indicate that the Fisher Test reflects the chance that the combinations would show even more attraction or more repulsion, given overall values. For example, pro-prefixed verbs with the SOUNDANDSPEECH tag show the strongest attraction, and all

${ }^{8}$ To save space, SOUNDANDSPEECH is abbreviated as SANDS in tables. 
other attractions are listed below that one. By contrast, $z a$-prefixed verbs with the SOUNDANDSPEECH tag show the strongest repulsion, and s-prefixed verbs with the CHANGEST tag are the most neutral relationship.

A further rearrangement of these data gives us another perspective on the semantic profiles of the prefixes, elaborating the visualization in Figure 2. Table 3 lists the semantic classes that are attracted to, neutral to, or repulsed from the five prefixes. Relationships involving Fisher Test p-values on the order of e-5 $(1 / 100,000)$ or lower are underlined, since these are strongest.

Table 3. Relationships between Prefixes and Semantic Classes

\begin{tabular}{llll}
\hline $\begin{array}{l}\text { prefix } \\
\text { pro- }\end{array}$ & Attracted & Neutral & Repulsed \\
SA- & IMPACT & $\begin{array}{l}\text { BEHAV, } \\
\text { CHANGEST }\end{array}$ \\
$z a-$ & SANDS & BEHAV & IMPACT \\
& $\underline{\text { IMPACT, }}$ & & SANDS, \\
$s-$ & CHANGEST & CHANGEST, SANDS, & \\
& BEHAV & IMPACT & CHANGEST \\
\hline \hline
\end{tabular}

The attractions offer a clear set of semantic peaks for the prefixes. Four of the prefixes are primarily attracted to only one semantic class (underlined in Table 3): pro- is attracted to SOUNDANDSPEECH, po- is attracted to CHANGEST, $z a$ - is attracted to IMPACT, and $s$ - is attracted to BEHAV. Po- and $z a$ - are more weakly attracted to SOUNDANDSPEECH and CHANGEST, respectively. $\mathrm{Na}$-, by contrast, is strongly attracted to both IMPACT and BEHAV. $Z a$ - is repulsed by both of the classes it is not attracted to, and strongly repulsed by SOUNDANDSPEECH. $S$ - has a neutral relationship with all the classes it is not attracted to, and thus is not repulsed by any of them. Clearly each prefix behaves differently and we can pinpoint where the differences lay.

The statistical study thus both supports our hypothesis that the Natural Perfectives have preferences for semantic classes and specifies what these preferences are. The following section analyzes in more detail the actual verbs that stand behind the numbers, interpreting the 
relationships between prefixes and semantic classes in terms of the meanings that are present in both verbs and prefixes.

\section{The Semantic Profiles of the Five Prefixes}

This section takes each prefix in turn, examining first the semantic class or classes that it is attracted to, the classes for which the prefix has a neutral relationship, and then the repulsions. The analysis is based on the verbs that were included in the statistical study; full lists of these verbs are found in the Appendix, following the order of presentation here, which starts with the prefix showing the strongest attraction, namely that of pro- to SOUNDANDSPEECH. Each analysis closes with a comparison of the meanings found among Natural Perfectives and those that have been proposed for each prefix in previous scholarship. It is important to keep in mind that the previously proposed meanings for prefixes pertain largely or entirely to the "nonempty" uses. Our approach is innovative in that we show how these meanings are relevant also for the use of prefixes in Natural Perfectives, where they have been presumed to be semantically "empty."

The semantic tags are of course only a rough measure of the meanings of verbs, which are certainly more multi-faceted. They are a good rough measure, as we see that strong patterns emerge. However, there are small residues of verbs in nearly all of the classes that are repulsed from various prefixes (except BEHAV, which has no verbs prefixed in pro-). It is essential to note that the few verbs in these repulsed classes are actually attracted to their prefixes, and as we see, this attraction is consistent with the overall pattern of the given prefix. This may seem counterintuitive, but it is possible because the meanings of the verbs are more complex than their semantic tags. For example, as we show below, pro- is best characterized as meaning 'through', and this meaning motivates quantification since movement through the space between points A and B covers a certain quantum of distance. The 'through' and 'quantification' aspects of pro- are compatible with the SOUNDANDSPEECH and IMPACT classes, as argued below. However, even though the CHANGEST class is less compatible with this meaning pattern, there are four pro-prefixed verbs in the CHANGEST class. These verbs are attracted to pro- because they signal penetration and thus encode 'through'. 


\subsection{The Semantic Profile of pro-}

When we look at the Natural Perfectives that are prefixed with pro-, a clear pattern emerges. Pro- is associated with movement 'through'. This meaning is most compatible with the semantic classes of SOUNDANDSPEECH and IMPACT. Either we are dealing with the emission of sounds, which is a penetration of sound waves through space (SOUNDANDSPEECH), or we see other kinds of penetration involving the drilling of holes or absorption of substances (IMPACT). Although pro- is repulsed from the CHANGEST semantic class, all the verbs that it does appear in for this class express some kind of penetration. There is additionally tangible overlap between the use of the prefix pro- in Natural Perfectives and its use in perdurative Complex Act Perfectives like proplakat' (vsju noč') 'cry through (the whole night)', since many of the Natural Perfectives, particularly those in the SOUNDANDSPEECH class, can also have a perdurative reading.

\subsubsection{Attraction: 51 SOUNDANDSPEECH Verbs (23 SOUND and 28 SPEECH)}

Making sounds entails sending them 'through' time, which motivates the attraction of pro- to this semantic class. A generic verb in this group serves as an umbrella term for many of the others: prozvučat' 'sound, be heard'. Some verbs in this group denote sounds that can be made by inanimate objects, like progudet' 'buzz', or the weather, as in progremet' 'thunder'. Many sounds are characteristic of certain animals, as in prolajat' 'bark' or promyčat' 'moo'. Parallel to the animal sounds are a number of sounds specific to human beings, such as probasit' 'talk in a deep voice' and probormotat' 'mutter'. Alternatively, a few verbs in the SPEECH class involve completion of a specified amount of talking (cf. the parallel to perduratives), such as prodiktovat' 'dictate' and prointerv'juirovat' 'interview'. These verbs arguably refer to the metaphorical penetration of an entire performance.

\subsubsection{Neutral: 10 IMPACT Verbs}

The theme of penetrating substances and making holes is salient with the IMPACT verbs that combine with pro-. Substances (here lime, disinfectant, and air) penetrate objects and spaces in proizvestkovat' 'apply 
lime (soil)', prodezinficirovat' 'apply disinfectant', proventilirovat' 'ventilate', and provejat' 'winnow'. Three verbs in the IMPACT class refer directly to the drilling of holes: proburavit' 'bore, drill', proburit' 'bore, drill', and prosverlit' 'drill, perforate'. The three remaining verbs involve opening up holes with specific instruments: protaranit' 'ram', promotyžit' 'hoe', and prodiskovat' 'break up soil with a disk-shaped harrow'.

\subsubsection{Repulsions: 0 BEHAV Verbs, 4 CHANGEST Verbs}

The BEHAV semantic class is not represented at all, which is not surprising given that behavior is not something that involves penetration or movement 'through' anything and behavior as a state is not often quantized in verbs. CHANGEST is likewise in general not very compatible with pro- because a change of state is often punctual and therefore resists quantization in a verb. However, the few verbs that we do find in the CHANGEST class reflect the overall pattern of pro-. There are four verbs, two of which encode saturation via penetration with a substance or flavor: propitat'sja 'become saturated' and progorknut' 'become bitter'. The other two verbs in the CHANGEST class involve penetration through holes: proxudit'sja 'become worn out (with holes)' and projasnet' 'clear up', in which sunlight penetrates the clouds.

\subsubsection{Comparison of the Semantic Profile of pro- with Previous Scholarship on pro-}

Flier (1975: 221-22) designates pro- as -LATERAL in a feature analysis, suggesting that its meanings include: 'through' (prolomit' stenu 'break through the wall'), 'thoroughness' (provarit' mjaso 'cook the meat thoroughly'), 'duration' (progovorit' celyj čas 'talk for a whole hour'), 'distance overcome' (proexat' desjat' kilometrov 'ride for ten kilometers'), and 'result' (proventilirovat' 'ventilate'). ${ }^{9}$ Švedova et al. (1980: §876) offer eight meanings, six of which correspond to Flier's meanings (though 'thoroughness' is broken up into two categories), plus two more, both of which involve missing something: 'move past' (proexat' in the sense of 'ride past') and 'fail to notice/be present' (progljadet'

\footnotetext{
${ }^{9}$ Flier (1975: 222) also recognizes an additional meaning, namely 'satisfaction' (prospat'sja 'sleep one's fill'), but states that this meaning shows "little productivity."
} 
'overlook'). ${ }^{10}$ The meanings of 'through' and 'thoroughness' for proare parallel to the use of pro- to perfectivize verbs that describe penetration, making holes, and saturation in the IMPACT and CHANGEST classes. Most of the SOUNDANDSPEECH verbs are also compatible with the 'result' meaning. Additionally, the connection between some Natural Perfectives and perduratives points to the presence of the 'duration' meaning. Some of the meanings that have been attributed to pro- are not found among our Natural Perfectives: 'move past' and 'fail to notice/be present'. These omissions are perhaps not surprising given that moving past something is not a natural culmination for moving and failing to notice something is not a natural culmination of an act of perception. Otherwise, however, we observe that the meanings associated with the pro-prefixed Natural Perfectives are a subset of the meanings that have been previously attributed to pro-.

\subsection{The Semantic Profile of po-}

The theme of po- is closely related to its use to form delimitative Complex Act Perfectives. This prefix is attracted to the CHANGEST class, where it combines with verbs that denote gradual changes along scales defined by adjectives. The result signaled by the po-prefixed Natural Perfectives is an increase along a given scale, parallel to the completion of some amount of an activity. We can compare, for example, the Natural Perfective poteplet' 'get warmer' with a Complex Act Perfective like poplakat' 'cry for a while', since in both cases we have a loosely quantified action, 'some warming' and 'some crying', that could potentially be continued at a later point in time. In the semantic classes that are neutral for po- or repulse this prefix, we find verbs that denote activities that necessarily have some duration, either brief as in the case of poblagodarit' 'say thank you' or potentially longer, as in posporit' 'have an argument'. Actions that are truly instantaneous are missing and many verbs are open to an alternative delimitative reading in addition to the "purely aspectual" reading of the Natural Perfectives. The association with the delimitative reading betrays a quantizing function

\footnotetext{
${ }^{10}$ Some uses can convey these meanings (cf. Mimo progroxotal gruzovik 'a truck rumbled by' (Krongauz 1998); Prokukovala ves' svoj vek, a teper' zlitsja 'She has wasted her life cuckooing and now she is angry' [Šukšin, Pis'mo (1970-72)]). However these are Specialized Perfectives.
} 
for $p 0^{-}$, and it is thus not surprising that po- is neutral toward BEHAV, since behavior is usually hard to quantify in a verb. The verbs that do appear with po- in the BEHAV class are exceptions to this rule, either verbs that describe quantizable behaviors, or uses that are simply resultative.

\subsubsection{Attraction: 62 CHANGEST Verbs, 37 SOUNDANDSPEECH Verbs (35 SPEECH and 2 SOUND)}

The verbs in this group are nearly all motivated by adjectival rather than verbal roots and thus best described as "factitives" (Townsend 1975: 143-44). At least one verb has instead a nominal root: posaxarit' 'sugar'. Three verbs have a verbal root: poseč'sja 'tear', potreskat'sja 'split', and pospet' 'ripen' (but note that the latter is closely associated with the adjective spelyj 'ripe'). Nearly half of the CHANGEST po-prefixed Natural Perfectives reference a change in color, such as pokrasnet' 'turn red', pobelet' 'turn white', and počernet' 'turn black'. Other verbs in this group refer to characteristics such as appearance (poxudet' 'get slimmer', pomolodet' 'get younger-looking'), temperature (poxolodet' 'cool down', poteplet' 'get warmer'), and other qualities (poredet' 'thin out', poumnet' 'grow wiser', polegčat' 'lessen, abate').

On the whole, these verbs are of the type Croft (forthcoming) refers to as "directed activities" and Mehlig (1994: 590) terms "relative transformatives", because most verbs in this group refer to situations that can be continued further after the completion denoted by the perfective verb. Thus one could potentially say on poxudel, a potom on ešče sil'nee poxudel 'he slimmed down and then he got even slimmer'. This type of perfective is thus a bit unusual since most perfective verbs do not leave room for a continuation of the same action; cf. the unacceptability of ${ }^{*}$ on napisal knigu, a potom ešč bol'še napisal knigu 'he wrote a book and then wrote the book even more'. However, delimitative Complex Act Perfectives also allow further continuation of a completed event, as in on poplakal, a potom ešč poplakal 'he cried for a bit and then did a bit more crying'. Thus there are two generalizations we can make concerning the po-prefixed CHANGEST verbs: (i) most of them are not formed from verbal roots, and (ii) their Natural Perfectives do not refer to a single definitive result, but rather the result of some change along a scale comparable to the completion of some amount of an activity in a delimitative Complex Act Perfective. 
The 35 SPEECH verbs include situations typically of shorter duration such as poblagodarit' 'thank', požalovat'sja 'complain', and poprosit' 'request'; as well as situations of variable duration such as pomolit'sja 'pray', posovetovat' 'give advice', and poxvastat'(sja) 'brag'. The latter are comparable to delimitative Specialized Perfectives such as pogovorit' 'talk for a while', porugat' 'curse for a while', and pokritikovat' 'criticize for a while'. The two SOUND verbs prefixed in po- are posmejat'sja 'laugh' and the colloquial verb pozvonit'sja 'ring'.

\subsubsection{Neutral: 11 BEHAV Verbs}

Most of the verbs in the BEHAV semantic class are motivated by nonverbal roots and/or can have a delimitative reading, as in požadničat' 'act greedy' and polenit'sja 'act lazy'. Additionally we see verbs that conform to neither of these trends, like poslušat'sja 'obey' and postesnjat'sja 'be shy', which are more generally resultative.

\subsubsection{Repulsion: 11 IMPACT Verbs}

The verbs in this group are resultative and refer either to well defined tasks, like pobrit'(sja) 'shave' and podoit' 'milk', or to various kinds of touching, as in poščupat' 'touch, feel', počesat'sja 'scratch', and poščckotat' 'tickle'. Again, many of these verbs are open to interpretation also as delimitatives.

\subsubsection{Comparison of the Semantic Profile of po- with Previous Scholarship on po-}

In this study, po-prefixed Natural Perfectives are primarily verbs denoting changes of state along a gradient scale, and are motivated by adjectival instead of verbal roots. Dickey (2006 and 2007) argues that for Russian po- is the "primary" perfectivizing prefix, which may be why it is the prefix of choice even for verbs that are motivated by adjectival roots. We see a continuum between the resultative reading (as in pobrit'sja 'shave') of Natural Perfectives with this prefix and an alternate delimitative reading (similar to počitat' 'read for a little while'). How does this square with the meanings of $p o$ - that have been identified not just for Natural Perfectives, but also for other types of perfective verbs? The most comprehensive recent work on po- is LeBlanc 
2010, presenting a statistical study of data from the RNC. For perfective verbs, LeBlanc identifies the following meanings of po-: resultative ('do $X$ to completion'), delimitative ('do $X$ for a while'), attenuative ('do a little bit of $X^{\prime}$ ), distributive ('do $X$ across all objects'), and ingressive ('begin to do $\left.X^{\prime}\right) .{ }^{11}$ The attenuative meaning, despite the fact that it is listed in major grammars, is apparently exceedingly rare in Modern Russian, since LeBlanc's study failed to discover any examples, so it can be put aside as a marginal phenomenon. ${ }^{12}$ The Natural Perfectives in our study, by contrast, are overwhelmingly resultative, though many form a continuum with the delimitative meaning, and this is consistent with LeBlanc's (2010: 98) observation of a close link between the resultative and delimitative meanings (Dickey (2006) tracks the historical connection between these meanings, along with Rassudova (1968: 97), Avilova (1976: 204-06), and Petruxina (2000: 148-49, 186$87)$ ). The distributive and ingressive meanings are, however, not observed among Natural Perfectives in po-. This is not surprising given the fact that these meanings are not entirely compatible with the purely perfectivizing function of a Natural Perfective, since a distributive puts focus instead on multiple situations and an ingressive puts focus on the beginning rather than completion of an action. In short, we see that the po-prefixed Natural Perfectives in our study have meanings that overlap with some of the meanings generally associated with po- ('resultative' and 'delimitative'), but do not overlap with others ('distributive' and 'ingressive').

\subsection{The Semantic Profile of za-}

The $z a$-prefixed Natural Perfectives mostly express either covering or putting something into a fixed state. Fixed states are achieved either literally (via attachment) or metaphorically, in which case the resultant state is one in which an object is less flexible and less vulnerable to change. Covering is compatible with the IMPACT class since covering

\footnotetext{
${ }^{11}$ Note that this list is consistent with the meanings listed in both standard grammars of Russian and in more specialized works pertaining to po-, such as Dmitrieva 1991. A sixth meaning, the intermittent-attenuative, is associated only with imperfective verbs.

${ }^{12}$ It is likely that LeBlanc did not find attenuative uses because his study focused mainly on written examples. These uses are probably more frequent in spoken language.
} 
impacts a surface, and both covering and change to a fixed state are compatible with CHANGEST. Both IMPACT and CHANGEST are attracted to $z a-$, accounting for nearly all of the $z a$-prefixed verbs. Only two verbs remain, one each in the SPEECH and BEHAV classes, both of which conform to the overall pattern in that they describe a change to a more fixed state.

\subsubsection{Attraction: 47 IMPACT Verbs, 22 CHANGEST Verbs}

Over half of the $z a$-prefixed verbs in the IMPACT class denote covering, such as zaasfal'tirovat' 'cover with asphalt', zamaskirovat'(sja) 'mask', and zamusolit' 'slobber all over'. A smaller subgroup applies something to a container rather than a surface, resulting in verbs of filling such as zabutit' 'fill with rubble' and zaballastirovat' 'load with ballast'. Covering often entails attachment, and the latter meaning is emphasized in verbs like zakrepit' 'fasten' and zatavrit' 'brand'. The fixing of attachment is related also to the achievement of fixed states in which something is less mobile and subject to change, as in zakonservirovat' 'preserve' and zakristallizovat' 'crystallize'. More metaphorical fixing is present in verbs like zabronirovat' 'reserve', where the right to access something becomes "fixed" through an agreement.

The CHANGEST verbs that use $z a$ - can likewise be grouped as involving covering (zagrjaznit'(sja) 'get dirty', zapylit'sja 'get covered with dust', zaindevet' 'become covered with frost') or fixed states (zamerznut' 'freeze', zatverdet' 'harden', zagustet' 'thicken').

\subsubsection{Repulsions: 1 SPEECH Verb, 1 BEHAV Verb}

Covering and change to a fixed state do not harmonize well with SOUNDANDSPEECH and BEHAVE. Each of these semantic classes contains only one $z a$-prefixed Natural Perfective. The SPEECH verb is zakontraktovat' 'make a contract' where the result is a fixed plan, and the BEHAV verb is zadurit' 'become unreasonable' where a human being reaches a fixed state that goes beyond the boundaries of acceptable behavior. 


\subsubsection{Comparison of the Semantic Profile of za- with Previous Scholarship on za-}

The $z a$-prefixed Natural Perfectives in our study exhibit the following kinds of meanings: 'covering', 'filling', 'attachment', and 'change to a more fixed state'. We can compare this with the range of meanings that have been posited by Janda (1986) for $z a-$, which are: 'deflection', 'fix', 'change of state', 'excess', 'inchoative', 'exchange', 'surface', 'cover', 'splatter', and 'fill'. We see that the meanings associated with the Natural Perfectives are a subset of the range of $z a$ - meanings identified by Janda. 'Fix' and 'attachment' refer to the same meaning and are closely related to the change of state meaning, which is restricted only to "change from 'normal' to 'abnormal', since in every case the trajector exchanges its canonical condition of health, activity, transience, pliability, and/or freedom, for an opposite state" (Janda 1986: 97). Janda has two versions of the 'covering' meaning, since 'splatter' "is identical to <cover> except that the trajector is a group of objects or a divisible object rather than a single mass"' (Janda 1986: 129). The 'fill' meanings correspond. However, $z a$ - also has a number of other meanings that are not represented among our Natural Perfectives, namely: 'deflection', 'excess', 'inchoative', 'exchange', and 'surface'. Again, these meanings of $z a$ - are quite specialized and thus probably less compatible with the function of Natural Perfectives. However, base verbs denoting covering, filling, attachment, and change to a fixed state can easily perfectivize with $z a-.{ }^{13}$

\subsection{The Semantic Profile of $s$ -}

Behavior is often spontaneous and thus sudden, motivating the only attraction we observe in the profile of s-, namely to the BEHAV class, and we note that many s-prefixed verbs in the BEHAV class can have

\footnotetext{
13 Though the names of the meanings are different, Zaliznjak's (2006: 311-28) network is very similar, containing the following major classifications (and their approximate correspondents in Janda's system): 'begin' (= 'inchoative'), 'become' (= 'change of state'), 'cover', 'fix', 'damage' (= 'excess'), 'get' (= 'exchange'), and 'space' (= 'deflection'). Braginsky (2008) presents a smaller network of three meanings for $z a-$, spatial, resultant, and inchoative, plus a set of rules to handle contextual variation. However, the same ideas of covering, filling, attachment, and change to a fixed state are represented, many under the heading of 'become established'.
} 
semelfactive readings. All other classes show a neutral relationship to $s$ - and they additionally include meanings that can be characterized as 'together' and 'down'.

\subsubsection{Attraction: 23 BEHAV Verbs}

Verbs in this group can have semelfactive Single Act Perfective readings in addition to their more neutral resultative Natural Perfective readings. These verbs refer to a single performance of something (often negative) that could potentially be repeated, and these verbs often have non-verbal roots. Examples include: sglupit' 'do something stupid', sxitrit' 'do something clever', smalodušničat' 'act like a coward (on one occasion)', and soriginal'ničat' 'do something original'.

\subsubsection{Neutral: 11 CHANGEST Verbs, 9 SPEECH Verbs, 23 IMPACT Verbs}

The CHANGEST verbs describe processes of aging, rotting, and becoming more compact, which arguably combine the meanings of 'together' and 'down', as we see in sostarit'(sja) 'age', sgnit' 'rot', and skondensirovat' 'condense'.

Most of the SPEECH verbs that have the $s$ - prefix are similar to the attracted BEHAV verbs. These verbs can have a semelfactive reading, like sostrit' 'make a witty remark' and skalamburit' 'make a pun', but some can also relate to the 'together' meaning, as in sformulirovat' 'formulate' (which involves putting words or ideas together).

Though the same raw number of $s$-prefixed verbs is associated with the IMPACT semantic class as with the BEHAV class, the former is a neutral relationship because the IMPACT class is more than twice as large as the BEHAV class, and 23 is nearly the same as the expected value based on frequency alone, which is 21 . The majority of s-prefixed verbs in the IMPACT class instantiate the 'together' meaning in which parts are joined to make a whole, as in sšit' 'sew', svjazat' 'tie, knit', and smasterit' 'craft, build'. This includes also the generic verb sdelat' 'make, do', which has more abstract uses as well. Some verbs in this group express a downward movement: srubit' 'chop down' and sžeč' 'burn down'. 


\subsubsection{Comparison of the Semantic Profile of $s$ - with Previous Scholarship on $s$ -}

Dickey and Janda (2009) trace the development of meanings of the sprefix in Russian. The spatial meanings of the Old Church Slavonic stprefix included a centripetal meaning, as in OCS sbniti se 'come together', and a downward-ablative meaning, as in OCS ştręsti 'shake off'. These two meanings are equivalent to the 'together' and 'down' meanings that characterize the s-prefixed Natural Perfectives analyzed in this section. Dickey (2005: 10) argues that both the 'centripetal'/'together' meaning and the 'downward-ablative' meaning contributed to the development of a more generalized 'resultative' meaning in Slavic. In addition to motion verbs, the 'centripetal'/'together' meaning was (and still is) present in verbs used to mean 'assemble' and 'build', which have an inherent result (cf. sšit' 'sew'). Similarly, verbs with the 'downward-ablative' meaning yield a result; for example OCS søkratiti/Russian sokratit' 'shorten' names a result achieved by 'cutting away' or by compression, thus including 'together'. In combination the two meanings support more general resultative interpretation, facilitating use with factitive verbs like sgustit' 'thicken'. The semelfactive is an innovation in Russian, motivated by the actional flexibility of the spatial meanings and their resultative extensions (see Dickey and Janda 2009).

The meanings we find among the s-prefixed Natural Perfectives are thus consistent with the meanings found for s-prefixed verbs in general, in keeping with the pattern observed thus far.

\subsection{The Semantic Profile of na-}

The semantic profile of $n a$ - is somewhat more diffuse than for the other prefixes, since it lacks the focus of having only one strongly attracted semantic class, and is instead similarly attracted to both IMPACT and BEHAV. There is a consistent focus throughout all the na-prefixed verbs on accumulation, either physically on a surface or more abstractly in terms of increased density or intensity. This focus on accumulation is compatible with IMPACT and BEHAV and to a lesser extent SPEECH. Accumulation is less relevant for most CHANGEST verbs since a change of state affects an entire object, but the few CHANGEST 
verbs that are perfectivized with $n a$ - are consistent with the accumulation meaning.

\subsubsection{Attractions: 31 IMPACT Verbs, 17 BEHAV Verbs}

Again the fact that the IMPACT class has over twice as many verbs overall should be kept in mind, since $n a$ - is equally attracted to both classes, despite the differences in raw numbers. The physical accumulation of substance on a surface is most consistently realized in the IMPACT class, where we find verbs like navoščit' 'wax' and namylit'(sja) 'soap'.

Accumulation is mostly metaphorical in the BEHAV class, usually referring to accumulation of negatively-evaluated behavior, as in nabezobrazničat' 'behave disgracefully' and naxuliganit' 'behave like a hooligan'. Note the parallel here to Specialized Perfectives with an 'accumulation' meaning, such as nagrešit' 'commit many sins' (as opposed to the Natural Perfective sogrešit' 'sin').

\subsubsection{Neutral: 8 SPEECH Verbs}

The SPEECH verbs are parallel to the BEHAV verbs in reporting a quantity of verbal behavior, as in nagrubit' 'be rude', naklevetat' 'gossip', and naproročit' 'prophesize'.

\subsubsection{Repulsion: 3 CHANGEST Verbs}

The CHANGEST verbs refer to accumulation in terms of filling a volume, be it with electrical charge in naèlektrizovat' 'electrify', or smoke in nadymit' 'fill with smoke'.

\subsubsection{Comparison of the Semantic Profile of na- with Previous Scholarship on na-}

Russell 1985 and Švedova et al. 1980 (361-62) identify the following meanings associated with na-: 'surface-oriented action' (napudrit' 'powder'), 'training' (naučit' 'teach'), 'resultative' (napugat' 'frighten'), 'accumulation' (nakupit' 'buy a lot of'), and 'intensive' (nagrešit' 'do a 
lot of sinning'). ${ }^{14}$ The examples betray the fact that all of these meanings are variations on the 'accumulation' meaning, involving an accumulation of powder on a surface, an accumulation of teaching leading to a result, and intensity achieved by accumulation. Thus the meanings of the na-prefixed Natural Perfectives reflects the same range of meanings found for $n a$-prefixed verbs in general.

\subsection{Summary of the Semantic Profiles of pro-, po-, za-, s-, and na-}

Table 4 summarizes the meanings that are found for the Natural Perfectives prefixed in $\mathrm{pro}^{-}, \mathrm{po-}_{-}, \mathrm{za-}, \mathrm{s}^{-}$, and $\mathrm{na-}$. The main point of this table is to show that the meanings of the verbs that use a given prefix are consistent, regardless of whether they appear in attracted or repulsed classes. In other words, even those few verbs that do appear in the repulsed classes have meanings that are compatible with the overall meaning pattern of the given prefix.

Table 4. Meanings of Verbs Associated with Semantic Profiles

\begin{tabular}{|c|c|c|c|}
\hline & $\begin{array}{c}\text { Meanings in } \\
\text { Attracted Classes }\end{array}$ & $\begin{array}{c}\text { Meanings in } \\
\text { Neutral Classes }\end{array}$ & $\begin{array}{c}\text { Meanings in } \\
\text { Repulsed Classes }\end{array}$ \\
\hline pro- & $\begin{array}{l}\text { sound penetration, } \\
\text { perdurative } \\
\text { (SANDS) }\end{array}$ & $\begin{array}{l}\text { penetrating surfaces, } \\
\text { making holes } \\
\text { (IMPACT) }\end{array}$ & $\begin{array}{l}\text { saturation, } \\
\text { penetration } \\
\text { through holes } \\
\text { (CHANGEST) }\end{array}$ \\
\hline po- & $\begin{array}{l}\text { factitive, delimitative, } \\
\text { resultative } \\
\text { (CHANGEST, SANDS) }\end{array}$ & $\begin{array}{l}\text { factitive, resultative, } \\
\text { delimitative } \\
\text { (BEHAV) }\end{array}$ & $\begin{array}{l}\text { resultative, } \\
\text { delimitative } \\
\text { (IMPACT) }\end{array}$ \\
\hline$z a-$ & $\begin{array}{l}\text { covering, filling, fixed } \\
\text { states, attachment } \\
\text { (IMPACT, CHANGEST) }\end{array}$ & 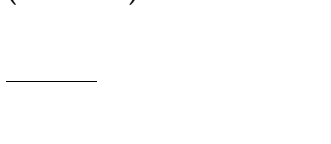 & $\begin{array}{l}\text { fixed states } \\
\text { (SPEECH, BEHAV) }\end{array}$ \\
\hline
\end{tabular}

\footnotetext{
14 Švedova et al. (1980: 362) additionally lists an unproductive 'superficial performance' meaning (naigrat' 'play superficially'), but Russell (1985: 73) notes that most sources associate this meaning only with imperfective verbs.
} 


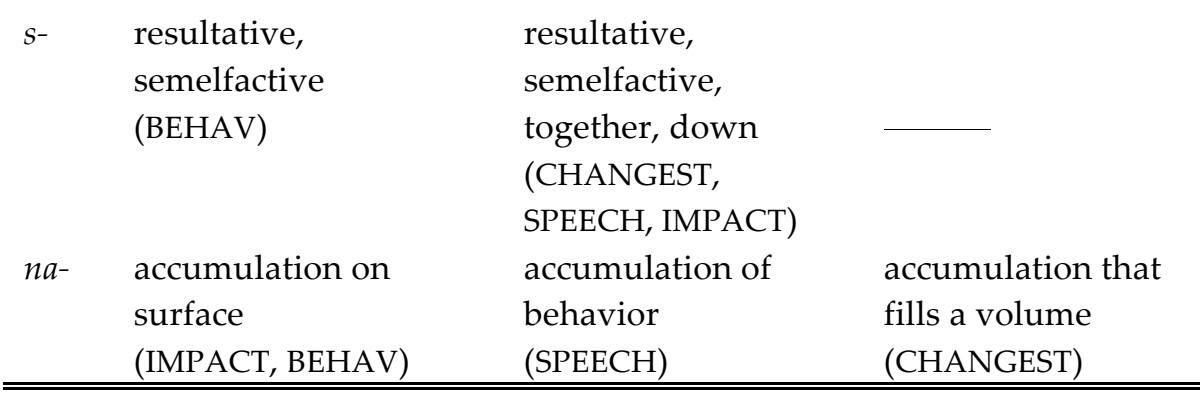

In all cases it is possible to describe the meanings of the prefixed Natural Perfectives as a subset of the meanings that have been posited for the corresponding prefixes. Even the meanings of the verbs representing semantic classes that are repulsed from a prefix are themselves consistent with the meaning of the prefix. For example, whereas prorepulses CHANGEST verbs overall, it can perfectivize CHANGEST verbs that denote saturation or penetration through holes. Prefixal meanings that are not attested among our Natural Perfectives are generally meanings that are phasal, very specific, or involve some kind of negation and thus are incompatible with the function of creating aspectual partner verbs with the same meaning as the imperfective simplex verbs. Thus we do not observe, for example, po-prefixed Natural Perfectives with an ingressive meaning, $z a$-prefixed Natural Perfectives with a deflection or ingressive meaning, or pro-prefixed Natural Perfectives with the meaning 'fail to notice'.

\section{Conclusions}

We have presented a methodology for investigating the semantics of verbal prefixes, namely semantic profiling. Semantic profiling uses the frequency distribution of semantic classes tagged on verbs with given prefixes to discover the semantic preferences of prefixes. The input consists of semantic classifications that have been independently assigned following the conventions of the Moscow semantic school. These data are therefore maximally accurate and informative and can be used in statistical tests.

We have shown that five of the verbal prefixes that are most widely used to form Natural Perfectives in Russian, pro-, po-, $z a^{-}, s^{-}$, and $n a-$, have unique semantic profiles. More specifically, we per- 
formed an analysis of the distribution of semantic tags in the RNC, with the result that each prefix is attracted to and repulsed by a different set of semantic classes. Our findings are both statistically significant and robust in their effect size. These findings support the hypothesis that Natural Perfectives associate with prefixes in accordance with semantic preferences. A detailed analysis of the prefixed verbs makes it possible to specify patterns of meanings and compare these patterns with the meanings that have been suggested for the prefixes in previous studies. We find that the meanings of the prefixed Natural Perfectives correspond well to the meanings of the prefixes. This is true despite the fact that the prefixes are purportedly "empty" in the Natural Perfectives and that the meanings of the prefixes have been established primarily on the basis of their "non-empty" uses. In other words, the meanings of the supposedly "empty" prefixed Natural Perfectives correspond to the meanings of the prefixes in their "nonempty" uses (in Specialized, Complex Act, and Single Act Perfectives). This result is consistent with the results of another study that focuses on a different set of prefixes and a different methodology: Baydimirova et al. submitted applied radial category profiling to examine most of the remaining prefixes, and found that the meanings of Natural Perfectives cover the same range or are a subset of the meanings of prefixes as established on the basis of their uses in other types of perfectives.

Returning to the perspective of tree structure, we recall that it has been argued (Ramchand 2004, Svenonius 2004a, 2004b, and 2008) that the meaning of the prefix is related to the prefix's position in the tree. The present results do not refute this claim, but rather elaborate it. One could state that the meanings of the prefixes are not only related to the position of the prefix in the tree, but are also related to the meanings of the verbs in the case of the so-called "purely aspectual" uses of prefixes. Indeed, all of these meanings cohere for any given prefix.

It appears then that a simplex verb selects the prefix that it uses to form a Natural Perfective according to semantic principles, choosing the prefix with the meaning that conforms best to the verb's own meaning. This study was limited to verbs that use only one prefix to form a Natural Perfective and have only one semantic tag. It was also limited to only five prefixes and did not take into account token frequency. Further research may show whether our conclusion can be corroborated while taking these and other factors into account. 


\section{References}

Alekseeva, A. P. (1978) Iz istorii pristavočnogo glagol'nogo slovoobrazovanija (na primere obrazovanij s $O B$ i O). Leningrad: Autoreferat.

Andrews, Edna. (1984) "A semantic analysis of the Russian prepositions/preverbs $\mathrm{O}(-)$ and $\mathrm{OB}(-)^{\prime \prime}$. Slavic and east European journal 28: 477-92.

Apresjan, Jurij D. (2005) “O moskovskoj semantičeskoj škole". Voprosy jazykoznanija 1: 3-30.

Avilova, Natalija S. (1959) "O kategorii vida v sovremennom russkom literaturnom jazyke". Russkij jazyk v nacional'noj škole 4: 21-26. . (1976) Vid glagola i semantika glagol'nogo slova. Moscow: Nauka.

Barykina, A. N., V. V. Dobrovol'skaja, and S. N. Merzon. (1979) Izučenie glagol'nyx pristavok. Moscow: Russkij jazyk.

Baydimirova, Anna. (2010) Russian aspectual prefixes $O, O B$, and $O B O$ : A case study of allomorphy. Master's thesis, University of Tromsø. Available at http://www.ub.uit.no/munin/handle/10037/2767.

Braginsky, Pavel. (2008) The semantics of the prefix ZA- in Russian. PhD dissertation, Bar-Ilan University, Israel.

Čertkova, Marina Ju. (1996) Grammatičeskaja kategorija vida v sovremennom russkom jazyke. Moscow: Moscow State University.

Cohen, Jacob. (1988) Statistical power analysis for the behavioral sciences. Mahwah, NJ: Lawrence Earlbaum Associates.

Cohen, Jacob, Patricia Cohen, Stephen G. West, and Leona S. Aiken. (2003) Applied multiple regression/correlation analysis for the behavioral sciences. Mahwah, NJ: Lawrence Earlbaum Associates.

Croft, William. (forthcoming) Verbs: Aspect and argument structure. Oxford: Oxford University Press.

Cubberly, Paul V. (1982) "On the 'empty' prefixes in Russian". Russian language journal 36: 14-30.

Dickey, Stephen M. (2005) "S-/Z- and the grammaticalization of aspect in Slavic". Slovene linguistic studies 5: 3-55.

. (2006) "Aspectual pairs, goal orientation, and PO- delimitatives in Russian". Glossos 7. Available at http://www.seelrc.org/ glossos/issues/7/.

. (2007) "A prototype account of the development of delimitative PO- in Russian". Dagmar Divjak and Agata Kochanska, eds. Cognitive paths into the Slavic domain. Berlin: Mouton de Gruyter, 326-71. 
Dickey, Stephen M. and Laura A. Janda. (2009) "Xoxotnul, sxitril: The relationship between semelfactives formed with $-n u$ - and $s$ - in Russian". Russian linguistics 33(3): 229-48.

Divjak, Dagmar and Stefan Th. Gries. (2006) "Ways of trying in Russian: Clustering behavioral profiles". Corpus linguistics and linguistic theory 2: 23-60.

Dmitrieva, Ol'ga. (1991) “Formirovanie semantičeskoj struktury russkogo glagol'nogo prefiksa po-". Lidija I. Barannikova, ed. Aktivnye processy $v$ jazyke $i$ reči. Saratov: Izdatel'stvo Saratovskogo universiteta, 68-74.

Endresen, Anna, Laura A. Janda, Julia Kuznetsova, Olga Lyashevskaya, Anastasia Makarova, Tore Nesset, Svetlana Sokolova. (submitted) "Russian 'purely aspectual' prefixes: Not so 'empty' after all?"

Endresen, Anna and Svetlana Sokolova. (2011) "Is UP always GOOD? A case of non-trivial evaluation in Russian prefixes". Paper presented at the 44th Annual Meeting of the Societas Linguistica Europaea. University of La Rioja, Logroño, Spain.

Evgen'eva, Anastasija P., ed. (1999) Slovar' russkogo jazyka v 4.x tt. Moscow: Russkij jazyk.

Flier, Michael S. (1975) "Remarks on Russian verbal prefixation". Slavic and east European journal 19(2): 218-29.

Forsyth, James A. (1970) A grammar of aspect. Cambridge: Cambridge University Press.

Gries, Stefan Th. and Dagmar S. Divjak. (2009) "Behavioral profiles: A corpus-based approach towards cognitive semantic analysis". Vyvyan Evans and Stephanie S. Pourcel, eds. New directions in cognitive linguistics. Amsterdam: John Benjamins, 57-75.

Hougaard, C. (1973) “Vyražaet li o-/ob- soveršaemost'?" Scando-Slavica 19: 119-25.

Isačenko, Aleksandr V. (1960) Grammatičeskij stroj russkogo jazyka v sopostavlenii s slovackim: Morfologija. Part 4. Bratislava: Jazyki slavjanskoj kul'tury.

Janda, Laura A. (1986) A semantic analysis of the Russian verbal prefixes ZA-, PERE-, DO-, and OT-. Munich: Otto Sagner. [Slavistische Beiträge, 192.]

- (2007) "Aspectual clusters of Russian verbs". Studies in language 31(3): 607-48. 
Janda, Laura A. and Olga Lyashevskaya. (2011a) “Grammatical profiles and the interaction of the lexicon with aspect, tense, and mood in Russian". Cognitive linguistics 22: 719-63.

_. (2011b) "Prefix variation as a challenge to Russian aspectual pairs: Are zavjaznut' and uvjaznut' 'get stuck' the same or different?" Russian linguistics 35: 147-67.

Janda, Laura A. and Valery Solovyev. (2009) "What constructional profiles reveal about synonymy: A case study of Russian words for SADNESS and HAPPINESS". Cognitive linguistics 20(2): 367-93.

King, Bruce M. and Edward Minium. (2008) Statistical reasoning in the behavioral sciences. Hoboken, NJ: John Wiley and Sons.

Krongauz, Maksim A. (1998) Pristavki i glagoly $v$ russkom jazyke: Semantičeskaja grammatika. Moscow: Jazyki russkoj kul'tury.

Kustova, Galina I., Olga N. Ljaševskaja, Elena V. Padučeva, and Ekaterina V. Raxilina. (2005) "Semantičeskaja razmetka leksiki v Nacional'nom korpuse russkogo jazyka: Principy, problemy, perspektivy". Nacional'nyj korpus russkogo jazyka: 2003-2005. Rezul'taty i perspektivy. Moscow: Institut russkogo jazyka im. V. V. Vinogradova, 155-74.

Kustova, Galina I., Olga N. Lashevskaja, Elena V. Paducheva, and Ekaterina V. Rakhilina. (2009) "Verb taxonomy: From theoretical lexical semantics to practice of corpus tagging". Barbara Lewandowska and Katarzyna Dziwirek, eds. Cognitive corpus linguistics studies. Frankfurt: Peter Lang, 41-56.

Kuznetsova, Julia. (2010) "Natural and non-natural perfectives: Prefix statistics". Presentation for the Cognitive Linguistics: Empirical Approaches to Russian research group, Tromsø.

Le Blanc, Nicholas L. (2010) The polysemy of an "empty" prefix: A corpusbased cognitive semantic analysis of the Russian verbal prefix po-. PhD dissertation, University of North Carolina at Chapel Hill.

Makarova, Anastasia and Laura A. Janda. (2009) "Do it once: A case study of the Russian -Hy-semelfactives". Scando-Slavica 55: 78-99.

Mehlig, Hans Robert. (1994) “Gomogennost' i geterogennost' v prostranstve i vremeni". Revue des études Slaves 66: 595-606.

Mironova, L. Ju. (2004) Vid glagola i sootnošenie leksiko-semantičeskix variantov mnogoznačnogo slova. Dissertation autoreferat, Tambov.

Nesset, Tore, Laura A. Janda, and Anna Endresen. (2011) "Two ways to get out: Radial category profiling and the Russian prefixes vyand iz-". Zeitschrift für Slawistik 56: 377-402. 
Ožegov, Sergej I. and Natal'ja Ju. Švedova. (2001) Slovar' russkogo jazyka. Moscow: Russkij jazyk.

Padučeva, Elena V. (2004) Dinamičeskie modeli v semantike leksiki. Moscow: Jazyki slavjanskix kul'tur.

Petruxina Elena. V. (2000) Aspektual'nye kategorii glagola v russkom jazyke $v$ sopostavlenii s nekotorymi drugimi slavjanskimi jazykami (vid $i$ fazisnovremennye sposoba glagol'nogo dejstvija). Moscow: Izdatel'stvo MGU.

Ramchand, Gillian. (2004) "Time and the event: The semantics of Russian prefixes". Nordlyd 32(2): 323-61.

Rassudova, Ol'ga P. (1968) Upotreblenie vidov glagola v russkom jazyke. Moscow: Izdatel'stvo MGU.

Roberts, C. B. (1981) "The origins and development of $o(b)$ - prefixed verbs in Russian with the general meaning 'deceive'". Russian linguistics 5: 217-33.

Russell, Pamela. (1985) "Aspectual properties of the Russian verbal prefix $-n a^{\prime \prime}$. Michael S. Flier and Alan Timberlake, eds. The scope of Slavic aspect. Columbus, OH: Slavica, 59-75.

Šaxmatov, Aleksej A. (1952) Učenie o častjax reči. Moscow: Učebnopedagogičeskoe izdatel'stvo.

van Schooneveld, C. H. (1958) “The so-called 'préverbes vides' and neutralization". Dutch contributions to the Fourth International Congress of Slavicists. Moscow, September 1958. The Hague: Mouton, 159-61.

Shull, Sarah. (2003) The experience of space: The privileged role of spatial prefixation in Czech and Russian. Munich: Otto Sagner. [Slavistische Beiträge, 419.]

Sokolova, Svetlana, Laura A. Janda, and Olga Lyashevskaya. (in press) “The locative alternation and the Russian 'empty' prefixes: A case study of the verb gruzit' 'load'". Dagmar Divjak and Stefan Th. Gries, eds. Frequency effects in cognitive linguistics: What statistical effects can(not) explain. Vol. 2. Berlin: Mouton de Gruyter. (Trends in Linguistics Series).

Švedova, Natal'ja Ju., N. D. Arutjunova, A. V. Bondarko, V. V. Lopatin, I. S. Uluxanov, and F. P. Filin. (1980) Russkaja grammatika. Vol. 1. Moscow: Nauka.

Svenonius, Peter. (2004a) "Slavic prefixes and morphology: An introduction to the Nordlyd volume". Nordlyd 32(2): 177-204. 
(2004b) "Slavic prefixes inside and outside VP". Nordlyd 32(2): 205-53.

- (2008). "Russian prefixes are phrasal". Formal description of Slavic languages: The fifth conference. Bern: Peter Lang, 526-37.

Timberlake, Alan. (2004) A reference grammar of Russian. Cambridge: Cambridge University Press.

Tixonov, Aleksandr N. (1964) "Čistovidovye pristavki v sisteme russkogo vidovogo formoobrazovanija". Voprosy jazykoznanija 1: 42-52.

. (1998) Russkij glagol. Moscow: Russkij jazyk.

Townsend, Charles E. (1975) Russian word formation. Columbus, OH: Slavica.

Vey, M. (1952) "Les préverbes 'vides' en tchèque moderne". Revue des études slaves 29: 82-107.

Vinogradov, Viktor V. (1972) Russkij jazyk. Moscow: Vysšaja škola.

Vinogradova, V. N. (1984) Stilističeskij aspekt russkogo slovoobrazovanija. Moscow: Izdatel'stvo Nauka.

Wade, Terence. (1992) A comprehensive Russian grammar. Oxford: Oxford University Press.

Zaliznjak, Anna A. (2006) Mnogoznačnost' v jazyke i sposoby ee predstavlenija. Moscow: Jazyki slavjanskix kul'tur.

Zaliznjak, Anna A. and Aleksej D. Šmelev. (1997) Lekcii po russkoj aspektologii. Munich: Otto Sagner.

—. (2000) Vvedenie v russkuju aspektologiju. Moscow: Jazyki russkoj kul'tury.

Faculty of Humanities, Social Sciences,

Received: May 2011 and Education

Revised: February 2012

University of Tromsø

N-9037 Tromsø

Norway

laura.janda@uit.no

Faculty of Philology

National Research University Higher School of Economics

Myasnitskaya str. 20

101000 Moscow

Russia

olesar@gmail.com 


\section{Appendix of Verbs and Semantic Tags}

The appendix is arranged according to the presentation of the semantic profiles in the article, with reference to corresponding section numbers.

\subsection{The Semantic Profile of pro-}

\subsubsection{Attraction: 51 SOUND and SPEECH Verbs (23 SOUND and 28 SPEECH)}

$\begin{array}{lll}\text { SPEECH } & \text { probasit' } & \text { 'talk in a deep voice' } \\ \text { SPEECH } & \text { probormotat' } & \text { 'mutter' } \\ \text { SOUND } & \text { probrenčat' } & \text { 'jingle' } \\ \text { SOUND } & \text { probrexat' } & \text { 'yelp, bark' } \\ \text { SPEECH } & \text { probrjuzžat' } & \text { 'grumble' } \\ \text { SOUND } & \text { probrjacat' } & \text { 'clank' } \\ \text { SPEECH } & \text { probubnit' } & \text { 'mutter' } \\ \text { SPEECH } & \text { proburčat' } & \text { 'grumble' } \\ \text { SOUND } & \text { provereščat' } & \text { 'squeal' } \\ \text { SPEECH } & \text { prově̌čat' } & \text { 'prophesy' } \\ \text { SOUND } & \text { progavkat' } & \text { 'bark' } \\ \text { SOUND } & \text { progogotat' } & \text { 'cackle' } \\ \text { SOUND } & \text { progremet' } & \text { 'thunder' } \\ \text { SOUND } & \text { progromyxat' } & \text { 'rumble' } \\ \text { SOUND } & \text { progroxotat' } & \text { 'crash, rumble' } \\ \text { SOUND } & \text { progudet' } & \text { 'buzz' } \\ \text { SPEECH } & \text { prodeklamirovat' } & \text { 'recite' } \\ \text { SPEECH } & \text { prodiktovat' } & \text { 'dictate' } \\ \text { SOUND } & \text { prozvenet' } & \text { 'ring' } \\ \text { SOUND } & \text { prozvučat' } & \text { 'sound, be heard' } \\ \text { SPEECH } & \text { proinstruktirovat' } & \text { 'instruct' } \\ \text { SPEECH } & \text { prointerv'juirovat' } & \text { 'interview' } \\ \text { SPEECH } & \text { proinformirovat' } & \text { 'inform' } \\ \text { SOUND } & \text { prokvakat' } & \text { 'croak' } \\ \text { SPEECH } & \text { prokommentirovat' } & \text { 'comment' }\end{array}$




\begin{tabular}{|c|c|c|}
\hline SPEECH & prokonsul'tirovat' & 'offer consultation' \\
\hline SPEECH & prokonsul'tirovat'sja & 'consult' \\
\hline SPEECH & prokričat' & ‘yell' \\
\hline SOUND & prokukarekat' & 'crow' \\
\hline SOUND & prokukovat' & 'cuckoo' \\
\hline SOUND & prolajat' & 'bark' \\
\hline SPEECH & prolepetat' & 'babble' \\
\hline SPEECH & prolopotat' & 'splutter' \\
\hline SOUND & promurlykat' & 'purr' \\
\hline SOUND & promyčat' & 'moo' \\
\hline SPEECH & promjamlit' & 'hum and haw' \\
\hline SOUND & promjaukat' & 'meow' \\
\hline SPEECH & propesočit' & 'criticize' \\
\hline SOUND & prosvistet' & 'whistle' \\
\hline SOUND & prosignalit' & 'signal' \\
\hline SPEECH & prosklonjat' & 'decline; bandy about' \\
\hline SPEECH & prosprjagat' & 'conjugate' \\
\hline SPEECH & protelegrafirovat' & 'telegraph' \\
\hline SPEECH & protelefonirovat' & 'telephone' \\
\hline SOUND & protjavkat' & ‘yelp’ \\
\hline SOUND & prourčat' & 'rumble' \\
\hline SPEECH & proxripet' & 'wheeze' \\
\hline SPEECH & procitirovat' & 'quote' \\
\hline SPEECH & prošeptat' & 'whisper' \\
\hline SPEECH & proèkzamenovat' & 'examine' \\
\hline SPEECH & proèkzamenovat'sja & 'be examined' \\
\hline
\end{tabular}

\subsubsection{Neutral: 10 IMPACT Verbs}

$\begin{array}{llll}\text { proburavit' } & \text { 'bore, drill' } & \text { proizvestkovat' } & \text { 'apply lime } \\ \text { proburit' } & \text { 'bore, drill' } & & \text { (soil)' } \\ \text { proventilirovat' } & \text { 'ventilate' } & \text { promotyžit' } & \text { 'hoe' } \\ \text { provejat' } & \text { 'winnow' } & \text { prosverlit' } & \text { 'drill, perforate' } \\ \text { prodezinficirovat' } & \text { 'apply disinfectant' } & \text { protaranit' } & \text { 'ram' } \\ \text { prodiskovat' } & \text { 'break up soil with a } & & \\ & \text { disk-shaped harrow' } & & \end{array}$




\subsubsection{Repulsions: 0 BEHAV Verbs, 4 CHANGEST Verbs}

\begin{tabular}{|c|c|c|c|}
\hline progorknut' & 'become bitter' & proxudit'sja & 'get worn out' \\
\hline propitat'sja & 'become saturated' & projasnet' & 'clear up' \\
\hline
\end{tabular}

\subsection{The Semantic Profile of po-}

\subsubsection{Attraction: 62 CHANGEST Verbs}

\begin{tabular}{|c|c|c|c|}
\hline pobagrovet' & 'turn purple' & poprostet' & 'become \\
\hline pobelet' & 'turn white' & & unpretentious' \\
\hline poblednet' & 'turn pale' & poredet' & 'thin out' \\
\hline pobleknut' & 'lose color' & porozovet' & 'turn pink' \\
\hline poburet' & 'turn brown' & poryžet' & 'turn reddish' \\
\hline povzroslet' & 'mature' & porjabet' & 'get speckled' \\
\hline povlažnet' & 'become damp' & posaxarit' & 'sugar' \\
\hline poglupet' & 'become stupid' & posvežet' & 'freshen' \\
\hline pogolubet' & 'turn blue' & posedet' & 'turn gray' \\
\hline podeševet' & 'become cheaper' & poseret' & 'turn grizzly' \\
\hline podlinnet' & 'become longer' & poser'eznet' & 'become serious' \\
\hline podorožat' & 'increase in price' & posečsja & 'tear' \\
\hline podurnet' & 'grow ugly' & posivet' & 'turn gray' \\
\hline poželtet' & 'turn yellow' & posizet' & 'turn blue-gray' \\
\hline pozdorovet' & 'turn recuperate' & posinet' & 'turn dark blue' \\
\hline pozelenet' & 'turn green' & posmirnet' & 'become quiet' \\
\hline pozelenit' & 'paint green' & posmuglet' & 'turn swarthy' \\
\hline pozlatit'sja & 'turn golden' & pospet' & 'ripen' \\
\hline pozolotet' & 'turn golden' & posurovet' & 'become severe' \\
\hline pokrasnet' & 'turn red' & poteplet' & 'get warmer' \\
\hline pokrupnet' & 'grow larger' & potončat' & 'become thin' \\
\hline polevet' & 'shift leftward' & potreskat'sja & 'split' \\
\hline polegčat' & 'lessen, abate' & potusknet' & 'turn dim' \\
\hline polilovet' & 'turn violet' & potusknut' & 'turn dim' \\
\hline pomolodet' & 'get younger-looking' & poumnet' & 'grow wiser' \\
\hline pomračnet' & 'turn dark' & poraledet & "cool down', \\
\hline pomutnet' & 'muddy' & poxolodnet' & 'cool down' \\
\hline
\end{tabular}




$\begin{array}{llll}\text { pomjagčet' } & \text { 'get soft' } & \text { poxorošet' } & \text { 'grow prettier' } \\ \text { poplotnet' } & \text { 'grow stout; become } & \text { poxrabret' } & \text { 'become braver' } \\ & \text { dense' } & \text { poxudat' } & \text { 'get slimmer' } \\ \text { popolnet' } & \text { 'grow stout' } & \text { poxudet' } & \text { 'get slimmer' } \\ \text { popravet' } & \text { 'shift rightward' } & \text { počernet' } & \text { 'turn black' }\end{array}$

\subsubsection{Attraction: 37 SOUND and SPEECH Verbs (2 SOUND: posmejat'sja 'laugh' and pozvonit'sja 'ring'; All Others Are SPEECH)}

$\begin{array}{llll}\text { poblagodarit' } & \text { 'thank' } & \text { poprosit' } & \text { 'request' } \\ \text { pobožit'sja } & \text { 'swear' } & \text { poprosit'sja } & \text { 'ask for' } \\ \text { povinit'sja } & \text { 'confess' } & \text { poručit'sja } & \text { 'guarantee' } \\ \text { povorožit' } & \text { 'tell fortunes' } & \text { posetovat' } & \text { 'complain' } \\ \text { pogutorit' } & \text { 'chat' } & \text { posmejat'sja } & \text { 'laugh' } \\ \text { požalit'sja } & \text { 'complain' } & \text { posovetovat'sja } & \text { 'get advice' } \\ \text { požalobit'sja } & \text { 'complain' } & \text { posporit' } & \text { 'argue' } \\ \text { požalovat'sja } & \text { 'complain' } & \text { posulit' } & \text { 'promise' } \\ \text { pozvat' } & \text { 'call' } & \text { posulit'sja } & \text { 'promise' } \\ \text { pozvonit'sja } & \text { 'ring' } & \text { potoropit' } & \text { 'hurry' } \\ \text { pozdorovat'sja } & \text { 'say hello' } & \text { potrebovat' } & \text { 'require' } \\ \text { pointeresovat'sja } & \text { 'be curious about' } & \text { poxvalit' } & \text { 'praise' } \\ \text { pokljast'sja } & \text { 'swear' } & \text { poxvalit'sja } & \text { 'boast' } \\ \text { polajat'sja } & \text { 'bark' } & \text { poxvastat' } & \text { 'brag' } \\ \text { pomolit'sja } & \text { 'pray' } & \text { poxvastat'sja } & \text { 'brag' } \\ \text { poobeščat' } & \text { 'promise' } & \text { poxodatajstvovat' } \\ \text { poobeščat'sja } & \text { 'promise' } & \text { 'intercede' } \\ \text { popenjat' } & \text { 'blame' } & \text { pocapat'sja } & \text { 'bicker' } \\ \text { poprivetstvovat' } & \text { 'welcome' } & \text { pošutit' } & \text { 'make a joke' } \\ & & \end{array}$

\subsubsection{Neutral: 11 BEHAV Verbs}

$\begin{array}{llll}\text { podelikatničat' } & \text { 'be soft on smby.' } & \text { poslušat'sja } & \text { 'obey' } \\ \text { požadničat' } & \text { 'act greedy' } & \text { postesnjat'sja } & \text { 'be shy' } \\ \text { pokuražit'sja } & \text { 'swagger' } & \text { potešit'sja } & \text { 'amuse' } \\ \text { polenit'sja } & \text { 'act lazy' } & \text { poxlopotat' } & \text { 'hustle about' }\end{array}$




$\begin{array}{llll}\begin{array}{l}\text { poostorožničat' } \\ \text { poskupit'sja }\end{array} & \text { 'be over-cautious' } & \text { poceremonit'sja } & \begin{array}{l}\text { 'stand on } \\ \text { ceremony' }\end{array}\end{array}$

\subsubsection{Repulsion: 11 IMPACT Verbs}

$\begin{array}{llll}\text { pobrit' } & \text { 'shave' } & \text { pokryt' } & \text { 'cover' } \\ \text { pobrit'sja } & \text { 'shave' } & \text { pokusat' } & \text { 'bite' } \\ \text { podoit' } & \text { 'milk' } & \text { počesat'sja } & \text { 'scratch oneself' } \\ \text { podrat'sja } & \text { 'fight' } & \text { poščekotat' } & \text { 'tickle' } \\ \text { pokolotit' } & \text { 'wallop' } & \text { poščupat' } & \text { 'touch, feel' } \\ \text { pokorobit' } & \text { 'warp' } & & \end{array}$

\subsection{The Semantic Profile of za-}

\subsubsection{Attraction: 47 IMPACT Verbs}

$\begin{array}{llll}\text { zaasfal'tirovat' } & \text { 'cover with } & \text { zamaskirovat' } & \text { 'mask' } \\ & \text { asphalt' } & \text { zamaskirovat'sja } & \text { 'mask' } \\ \text { zaballastirovat' } & \text { 'load with ballast' } & \text { zamesit' } & \text { 'knead' } \\ \text { zabarrikadirovat' } & \text { 'barricade' } & \text { zaminirovat' } & \text { 'mine' } \\ \text { zabarrikadirovat'sja } & \text { 'barricade } & \text { zamordovat' } & \text { 'victimize' } \\ & \text { oneself' } & \text { zamusolit' } & \text { 'slobber all } \\ \text { zabetonirovat' } & \text { 'concrete' } & & \text { over' } \\ \text { zabintovat' } & \text { 'bandage' } & \text { zamyzgat' } & \text { 'make filthy' } \\ \text { zabodat' } & \text { 'gore' } & \text { zaplatat' } & \text { 'patch' } \\ \text { zabronirovat' } & \text { 'reserve' } & \text { zaprudit' } & \text { 'dam up' } \\ \text { zabutit' } & \text { 'fill with rubble' } & \text { zapjatnat' } & \text { 'soil' } \\ \text { zavualirovat' } & \text { 'veil' } & \text { zasilosovat' } & \text { 'store in a silo' } \\ \text { zagatit' } & \text { 'make a } & \text { zaskirdovat' } & \text { 'mow up' } \\ & \text { brushwood road' } & & \\ \text { zagipsovat' } & \text { 'cover with } & \text { zasuslit' } & \text { 'slobber all } \\ & \text { gypsum' } & & \text { over' } \\ \text { zagudronirovat' } & \text { 'cover road with } & \text { zasusolit' } & \text { 'slobber all } \\ & \text { tar' } & & \text { over, suck' } \\ \text { zadekorirovat' } & \text { 'decorate' } & \text { zatavrit' } & \text { 'brand' } \\ \text { zadrapirovat' } & \text { 'drape' } & \text { zatorcevat' } & \text { 'trim' }\end{array}$




$\begin{array}{llll}\text { zadrapirovat'sja } & \text { 'drape' } & \text { zatuševat' } & \text { 'shade' } \\ \text { zazubrit'sja } & \text { 'get notched' } & \text { zatjukovat' } & \text { 'pack in bales' } \\ \text { zakamuflirovat' } & \text { 'camouflage' } & \text { zaxloroformirovat' } & \text { 'chloroform' } \\ \text { zakonservirovat' } & \text { 'preserve' } & \text { zašnurovat'sja } & \text { 'lace up' } \\ \text { zakrepit' } & \text { 'fasten' } & \text { zašpaklevat' } & \text { 'putty' } \\ \text { zakristallizovat' } & \text { 'crystallize' } & \text { zašpuntovat' } & \text { 'groove' } \\ \text { zalatat' } & \text { 'patch' } & \text { zaštopat' } & \text { 'darn' } \\ \text { zamarkirovat' } & \text { 'mark' } & \text { zaštukovat' } & \text { 'mend' }\end{array}$

\subsubsection{Attraction: 22 CHANGEST Verbs}

$\begin{array}{llll}\text { zavšivet' } & \text { 'become lousy' } & \text { zamusolit'sja } & \text { 'get covered with } \\ \text { zagrjaznit' } & \text { 'make dirty' } & & \text { slobber' } \\ \text { zagrjaznit'sja } & \text { 'get dirty' } & \text { zaplesnevet' } & \text { 'become moldy' } \\ \text { zagustet' } & \text { 'thicken' } & \text { zapylit'sja } & \text { 'get covered with dust' } \\ \text { zaindevet' } & \text { 'get covered } & \text { zarubcevat'sja } & \text { 'get covered with a } \\ & \text { with frost' } & & \text { scar' } \\ \text { zakonspirirovat' } & \text { 'make secret' } & \text { zastudenet' } & \text { 'become jellied' } \\ \text { zakosnet' } & \text { 'stagnate' } & \text { zatverdet' } & \text { 'harden' } \\ \text { zalubenet' } & \text { 'harden' } & \text { zatravenet' } & \text { 'get covered with } \\ \text { zamarinovat' } & \text { 'marinate' } & & \text { grass' } \\ \text { zamerznut' } & \text { 'freeze' } & \text { zaxilet' } & \text { 'become sickly' } \\ \text { zamuslit'sja } & \text { 'get covered } & \text { zaxiret' } & \text { 'fall into decay' } \\ & \text { with slobber' } & \text { začaxnut' } & \text { 'wither' } \\ & & \text { zašeršavet' } & \text { 'become rough' }\end{array}$

\subsubsection{Repulsions: 1 SPEECH verb (zakontraktovat' 'make a contract'), 1 BEHAV verb (zadurit' 'become unreasonable')}




\subsection{The Semantic Profile of $s$ -}

\subsubsection{Attraction: 23 BEHAV Verbs}

\begin{tabular}{|c|c|}
\hline svelikodušničat' & $\begin{array}{l}\text { 'do something } \\
\text { generous' }\end{array}$ \\
\hline sglupit' & $\begin{array}{l}\text { 'do something } \\
\text { stupid' }\end{array}$ \\
\hline sdvurušničat' & 'be a double-dealer' \\
\hline s"exidničat' & 'speak maliciously' \\
\hline sžulit' & 'cheat' \\
\hline sžul'ničat' & 'cheat' \\
\hline slevačit' & 'work on the side' \\
\hline sliberal'ničat' & 'play the liberal' \\
\hline slovčit' & ‘dodge' \\
\hline slukavit' & 'be cunning' \\
\hline smalodušestvovat' & $\begin{array}{l}\text { 'act like a coward } \\
\text { (once)' }\end{array}$ \\
\hline smalodušničat' & $\begin{array}{l}\text { 'act like a coward } \\
\text { (once)' }\end{array}$ \\
\hline
\end{tabular}

$\begin{array}{ll}\text { smošenničat' } & \text { 'cheat' } \\ \text { smuxlevat' } & \text { 'swindle' } \\ \text { snaxal'ničat' } & \text { 'be impudent' } \\ \text { sobez'janničat' } & \text { 'ape' } \\ \text { sozorničat' } & \text { 'play tricks' } \\ \text { soriginal'ničat' } & \text { 'do something } \\ & \text { original' } \\ \text { spodličat' } & \text { 'act meanly' } \\ \text { sprovocirovat' } & \text { 'provoke' } \\ \text { sxalturit' } & \text { 'do something } \\ & \text { carelessly' } \\ \text { sximičit' } & \text { 'contrive' } \\ \text { sxitrit' } & \text { 'do something } \\ & \text { clever' }\end{array}$

\subsubsection{Neutral: 11 CHANGEST Verbs}

$\begin{array}{llll}\text { svarit'sja } & \text { 'get cooked' } & \text { smjagčit' } & \text { 'make softer' } \\ \text { sgnit' } & \text { 'rot' } & \text { sostarit' } & \text { 'age' } \\ \text { sgnoit' } & \text { 'let rot' } & \text { sostarit'sja } & \text { 'age' } \\ \text { sžat'sja } & \text { 'shrink' } & \text { stvorožit' } & \text { 'curdle' } \\ \text { skondensirovat' } & \text { 'condense' } & \text { stvorožit'sja } & \text { 'curdle' } \\ \text { skosobočit'sja } & \text { 'get lopsided' } & & \end{array}$

\subsubsection{Neutral: 9 SPEECH verbs}

$\begin{array}{llll}\text { sagitirovat' } & \text { 'campaign for' } & \text { srifmovat' } & \text { 'make a rhyme' } \\ \text { skalamburit' } & \text { 'make a pun' } & \text { storgovat'sja } & \text { 'strike a bargain' } \\ \text { skomandovat' } & \text { 'command' } & \text { sformulirovat' } & \text { 'formulate' } \\ \text { sorientirovat' } & \text { 'orient' } & \text { s'jazvit' } & \text { 'say sth sarcastic' } \\ \text { sostrit' } & \text { 'make a witty } & & \end{array}$


remark'

\subsubsection{Neutral: 23 IMPACT Verbs}

$\begin{array}{llll}\text { sbrošjurovat' } & \text { 'stitch up' } & \text { smontirovat' } & \text { 'mount' } \\ \text { svarganit' } & \text { 'knock off' } & \text { sostrjapat' } & \text { 'cook' } \\ \text { svarit' } & \text { 'cook' } & \text { srabotat' } & \text { 'work out' } \\ \text { svit' } & \text { 'twist; weave' } & \text { sravnjat' } & \text { 'even out' } \\ \text { svjazat' } & \text { 'tie, knit' } & \text { srubit' } & \text { 'chop down' } \\ \text { sdelat' } & \text { 'make, do' } & \text { ssučit' } & \text { 'twist' } \\ \text { sžat' } & \text { 'reap' } & \text { strenožit' } & \text { 'hobble' } \\ \text { sžeč' } & \text { 'burn down' } & \text { sfabrikovat' } & \text { 'fabricate' } \\ \text { skomkat' } & \text { 'crumple' } & \text { sfal'cevat' } & \text { 'fold' } \\ \text { skopnit' } & \text { 'stook' } & \text { sfugovat' } & \text { 'joint' } \\ \text { skulemat' } & \text { 'crumple' } & \text { sšit' } & \text { 'sew' } \\ \text { smasterit' } & \text { 'craft, build' } & & \end{array}$

\subsection{The Semantic Profile of na-}

\subsubsection{Attractions: 31 IMPACT Verbs}

$\begin{array}{llll}\text { nabelit'sja } & \text { 'whiten' } & \text { naoxrit' } & \text { 'apply ochre' } \\ \text { nabronzirovat' } & \text { 'bronze' } & \text { napičkat' } & \text { 'force-feed' } \\ \text { navaksit' } & \text { 'polish (shoe)' } & \text { naploit' } & \text { 'quill' } \\ \text { navorsit' } & \text { 'tease (fibers)' } & \text { napomadit' } & \text { 'pomade' } \\ \text { navorsovat' } & \text { 'tease (fibers)' } & \text { napomadit'sja } & \text { 'pomade oneself' } \\ \text { navoščit' } & \text { 'wax' } & \text { napryskat' } & \text { 'sprinkle' } \\ \text { nagljancevat' } & \text { 'glaze' } & \text { nasandalit' } & \text { 'apply sandalwood' } \\ \text { nagofrirovat' } & \text { 'crimp' } & \text { nasur'mit' } & \text { 'cover with surma' } \\ \text { nakanifolit' } & \text { 'apply rosin' } & \text { nasur'mit'sja } & \text { 'paint oneself with } \\ \text { nakostyljat' } & \text { 'give a good } & & \text { dye' } \\ & \text { drubbing' } & \text { nafabrit' } & \text { 'stain (mustaches)' } \\ \text { nakraxmalit' } & \text { 'starch' } & \text { nafabrit'sja } & \text { 'stain (mustaches)' } \\ \text { namalevat'sja } & \text { 'paint (one's face)' } & \text { naxoxlit' } & \text { 'ruffle up' } \\ \text { namelit' } & \text { 'chalk' } & \text { našinkovat' } & \text { 'shred' } \\ \text { namylit' } & \text { 'soap' } & \text { našpigovat' } & \text { 'apply lard' }\end{array}$




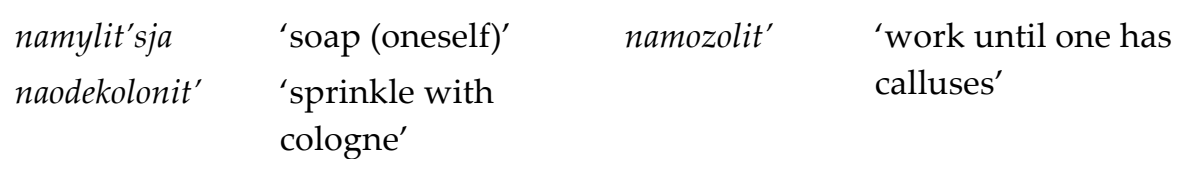

\subsubsection{Attractions: 17 BEHAV Verbs}

\begin{tabular}{|c|c|c|c|}
\hline nabedokurit' & 'get into mischief' & nakaverzničat' & 'make tricks' \\
\hline nabezobrazničat' & 'behave & nakurolesit' & 'play tricks' \\
\hline & disgracefully' & naplevat' & 'spit' \\
\hline nabuzit' & 'make a row' & naprokazit' & 'play pranks' \\
\hline nagrubijanit' & 'be rude' & naprokazničat' & 'play pranks' \\
\hline nadeboširit' & 'kick up a row' & napyžit'sja & 'puff up' \\
\hline naerundit' & 'play the fool' & nasvinjačit' & 'make a dirty act' \\
\hline nakaverzit' & 'make tricks' & naxuliganit' & $\begin{array}{l}\text { 'behave like a } \\
\text { hooligan' }\end{array}$ \\
\hline
\end{tabular}

\subsubsection{Neutral: 8 SPEECH Verbs}

$\begin{array}{llll}\text { nagrubit' } & \text { 'be rude' } & \text { naproročit' } & \text { 'prophesize' } \\ \text { naderzit' } & \text { 'be fresh with smb.' } & \text { naspletničat' } & \text { 'gossip' } \\ \text { naklevetat' } & \text { 'gossip' } & \text { naxamit' } & \text { 'be rude' } \\ \text { nakljauzničat' } & \text { 'libel' } & \text { najabedničat' } & \text { 'snitch' }\end{array}$

\subsubsection{Repulsion: 3 CHANGEST Verbs}

$\begin{array}{ll}\text { nadymit' } & \text { 'fill with smoke' } \\ \text { naxolodit' } & \text { 'cool' }\end{array}$

